\title{
Eulerian Simulation of the Perforation of Aluminum Plates by Nondeforming Projectiles
}

S. A. Silling

\section{Prepared by}

Sandia National Laboratories

Albuquerque, New Mexico 87185 and Livermore, Calıfornıa 94550

for the United States Department of Energy

under Contract DE-AC04-76DP00789

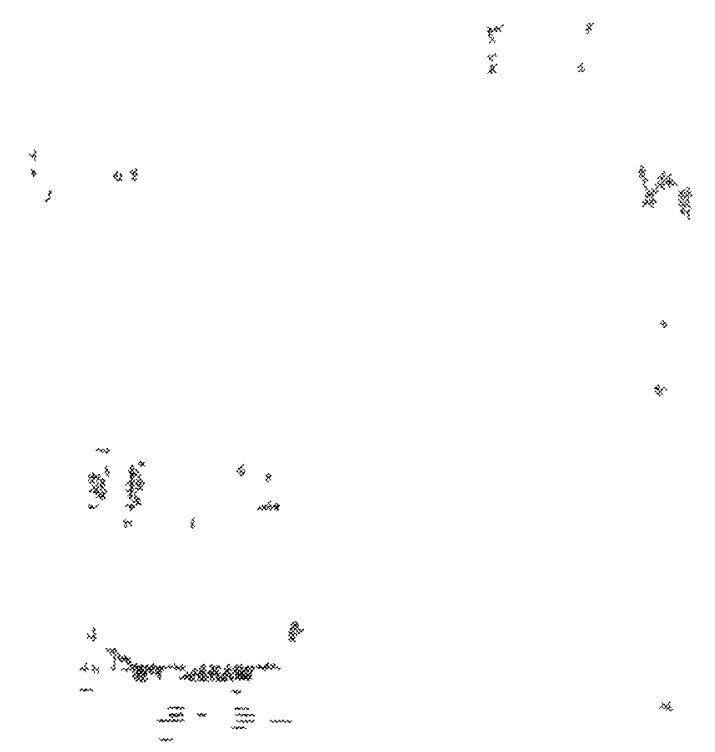




\section{DISCLAIMER}

This report was prepared as an account of work sponsored by an agency of the United States Government. Neither the United States Government nor any agency Thereof, nor any of their employees, makes any warranty, express or implied, or assumes any legal liability or responsibility for the accuracy, completeness, or usefulness of any information, apparatus, product, or process disclosed, or represents that its use would not infringe privately owned rights. Reference herein to any specific commercial product, process, or service by trade name, trademark, manufacturer, or otherwise does not necessarily constitute or imply its endorsement, recommendation, or favoring by the United States Government or any agency thereof. The views and opinions of authors expressed herein do not necessarily state or reflect those of the United States Government or any agency thereof. 


\section{DISCLAIMER}

Portions of this document may be illegible in electronic image products. Images are produced from the best available original document. 
Issued by Sandia National Laboratories, operated for the United States Department of Energy by Sandia Corporation.

NOTICE: This report was prepared as an account of work sponsored by an agency of the United States Government. Neither the United States Government nor any agency thereof, nor any of their employees, nor any of their contractors, subcontractors, or their employees, makes any warranty, express or implied, or assumes any legal liability or responsibility for the accuracy, completeness, or usefulness of any information, apparatus, product, or process disclosed, or represents that its use would not infringe privately owned rights. Reference herein to any specific commercial product, process, or service by trade name, trademark, manufacturer, or otherwise, does not necessarily constitute or imply its endorsement, recommendation, or favoring by the United States Government, any agency thereof or any of their contractors or subcontractors. The views and opinions expressed herein do not necessarily state or reflect those of the United States Government, any agency thereof or any of their contractors.

Printed in the United States of America. This report has been reproduced directly from the best available copy.

Available to DOE and DOE contractors from

Office of Scientific and Technical Information

PO Box 62

Oak Ridge, TN 37831

Prices available from (615) 576-8401, FTS 626-8401

Available to the public from

National Technical Information Service

US Department of Commerce

5285 Port Royal Rd

Springfield, VA 22161

NTIS price codes

Printed copy: A03

Microfiche copy: A01 
SAND92-0493

\title{
Eulerian Simulation of the Perforation of Aluminum Plates by Nondeforming Projectiles
}

\author{
S. A. Silling \\ Computational Physics and Mechanics Division \\ Sandia National Laboratories \\ Albuquerque, New Mexico 87185
}

\begin{abstract}
A new algorithm for the treatment of sliding interfaces between solids with or without friction in an Eulerian wavecode is described. The algorithm has been implemented in the two-dimensional version of the CTH code. The code was used to simulate penetration and perforation of aluminum plates by rigid, conical-nosed tungsten projectiles. Comparison with experimental data is provided.
\end{abstract}

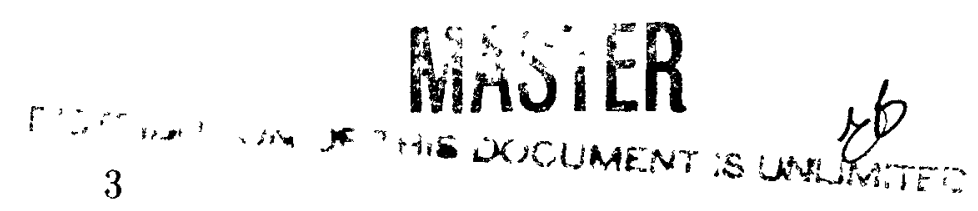




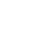




\section{Contents}

1. Introduction . . . . . . . . . . . . . . . . . . . . . 7

2. Problem Description . . . . . . . . . . . . . . . . . . 9

3. Boundary Layer Algorithm . . . . . . . . . . . . . . . . 13

4. Numerical Simulations . . . . . . . . . . . . . . . . . 27

5. Discussion . . . . . . . . . . . . . . . . . . . . . . 39

References . . . . . . . . . . . . . . . . . . . . . . . 41 


\section{Figures}

2.1 Projectile shape. . . . . . . . . . . . . . . . . . . . . 10

2.2 Stress-strain curves for the target material. . . . . . . . . . . . 11

3.1 CTH result without the boundary layer algorithm. . . . . . . . . 14

3.2 Flow chart for the interface definition algorithm. . . . . . . . . . 16

3.3 Interface layer. . . . . . . . . . . . . . . . . . . . . 17

3.4 Hard and soft boundary layers. . . . . . . . . . . . . . . . 19

3.5 Structure of the soft boundary layer. . . . . . . . . . . . . . 20

3.6 Placement of layers with respect to the material interface. . . . . . . 21

3.7 Flow chart for the boundary layer definition algorithm. . . . . . . . 22

3.8 Evaluation of boundary layer average velocities. . . . . . . . . . 24

3.9 Calculation of the direction vector $\mathbf{u}$ for frictional forces. . . . . . . 25

4.1 CTH result for the finely zoned mesh, with and without friction. . . . . 28

4.2 CTH result for the coarsely zoned mesh, with and without friction. . . . 29

4.3 Comparison of frictionless results for the two meshes. . . . . . . . 30

4.4 Comparison of frictionless calculations in the two meshes for an impact velocity of $810 \mathrm{~m} / \mathrm{s}$. . . . . . . . . . . . . . . . . . . . . 31

4.5 Details of emerging penetrator shapes, frictionless, impact velocity $810 \mathrm{~m} / \mathrm{s}$. 32

4.6 Contours of equivalent plastic strain. . . . . . . . . . . . . . 34

4.7 Residual velocities for variations with impact velocity $810 \mathrm{~m} / \mathrm{s}$. . . . . 35

4.8 Distribution of frictional body force density. . . . . . . . . . . . 36

4.9 Results with (right) and without (left) the Johnson-Cook fracture model, impact velocity $810 \mathrm{~m} / \mathrm{s}$. Shading indicates damage. . . . . . . . . 37 


\section{Introduction}

In an Eulerian wavecode, in contrast to a Lagrangian wavecode, the numerical mesh is fixed in space rather than tied to material particles in a deforming body. The main advantage of the Eulerian approach is that, because the mesh does not deform, there are no problems with excessive mesh distortion (such as a decrease in the time step size due to distorted zones or elements). Thus, Eulerian methods are desirable for applications involving very large deformations. Penetration problems are included in this class of applications.

Very large deformations occur near the tip of a penetrator moving through a target. Some special techniques have been developed for Lagrangian wavecodes to permit simulation of this type of problem. Among these are pilot holes, which introduce a hole through the target directly along the expected path of the tip of the penetrator. This is an easy technique to use in normal impact problems because the path is simply a straight line normal to the target surface. However, in oblique impact problems, the path of the penetrator tip cannot be determined in advance, and the analyst must evaluate it iteratively by performing several simulations of the problem. Another useful technique is rezoning, which eliminates the highly distorted Lagrangian zones or elements that dominate the time step. Eroding slide-lines represent a promising technique which is at present under development.

Because of the need for these special methods in Lagrangian codes for simulating penetration problems, it seems highly desirable to have an accurate Eulerian code for this purpose. However, Eulerian codes have difficulties of their own. Among these problems is the inherent complexity of algorithms for the treatment of mixed cells, which are cells containing multiple materials or a material plus void. Also, interactions along sliding surfaces are more difficult to treat in an Eulerian setting than with a Lagrangian approach. These two problems create the need for the algorithm described in this report.

The algorithm described here, which will be called the boundary layer algorithm, allows simulation of sliding solid surfaces with or without friction. Its main feature is that it helps to preserve the shape of a nearly rigid penetrator going through a target composed of a softer material. Without this algorithm, the effect of the mixing of materials within cells along the interface excessively erodes hard penetrators, contrary to experimental observations, and may drastically change their shapes. The algorithm for two dimensions was implemented in CTH [1], an Eulerian wavecode that is in wide use for the simulation of impact and penetration (see, for example, Anderson and Walker [2]).

The specific application discussed in this report is the perforation of an aluminum 
plate by conical-nosed tungsten projectiles [3]. Section 2 of this report gives a statement of the problem to be simulated. Section 3 describes the boundary layer algorithm for two dimensions. Section 4 contains numerical results obtained using a version of CTH modified to contain the algorithm described here. 


\section{Problem Description}

Forrestal, Luk, and Brar [3] performed experiments on and modeled analytically the perforation of 5083-H131 aluminum plates by conical-nosed tungsten projectiles. The projectile shape is shown in Figure 2.1. Impact was normal to within $2.7^{\circ}$. This report concerns only the experiments on target plates with a thickness of $50.8 \mathrm{~mm}$. The range of impact velocities was from $506 \mathrm{~m} / \mathrm{s}$ to $1176 \mathrm{~m} / \mathrm{s}$ (the ballistic limit was about 513 $\mathrm{m} / \mathrm{s})$.

The densities of the aluminum and tungsten were $2660 \mathrm{~kg} / \mathrm{m}^{3}$ and $18,500 \mathrm{~kg} / \mathrm{m}^{3}$ respectively. The tungsten, for purposes of this analysis, was treated as an elasticperfectly plastic material with a yield stress of $2000 \mathrm{MPa}$. Forrestal, Luk, and Brar [3] obtained compressive stress-strain data for the aluminum. For the present study, these data were fitted with the following power law hardening equation: $Y=A+B \varepsilon^{n}$, where $A=276 \mathrm{MPa}, B=187 \mathrm{MPa}$, and $n=0.3657$. Because the test used to obtain the stressstrain data was quasistatic and the test specimen was fairly thin (about $0.5 \mathrm{~cm}$ diameter), conditions were probably close to isothermal. Since it seems possible for heating during a penetration event to affect the plastic response, a correction was applied to the above isothermal stress-strain law. The correction was taken from the Johnson-Cook plasticity model [4]. The final form used in the calculations described in the rest of this report was as follows:

$$
Y=\left(A+B \varepsilon^{n}\right)\left(1-\left(\frac{T-300 \mathrm{~K}}{T_{M}-300 \mathrm{~K}}\right)^{m}\right)
$$

where $T_{M}$ is the melting temperature and $m$ is a constant. The values used were $T_{M}=775 \mathrm{~K}$ and $m=1.0$, both of which are tabulated values for 2024-T351 aluminum [4]. Stress-strain curves are shown in Figure 2.2 for the isothermal and adiabatic cases. The adiabatic curve was computed using a specific heat of $879 \mathrm{~J} \mathrm{~kg}^{-1} \mathrm{~K}^{-1}$.

X-ray photographs showed that up to velocities of about $1200 \mathrm{~m} / \mathrm{s}$, the projectile remained essentially undeformed after perforating the plate. Residual velocities were measured from X-ray photographs. 


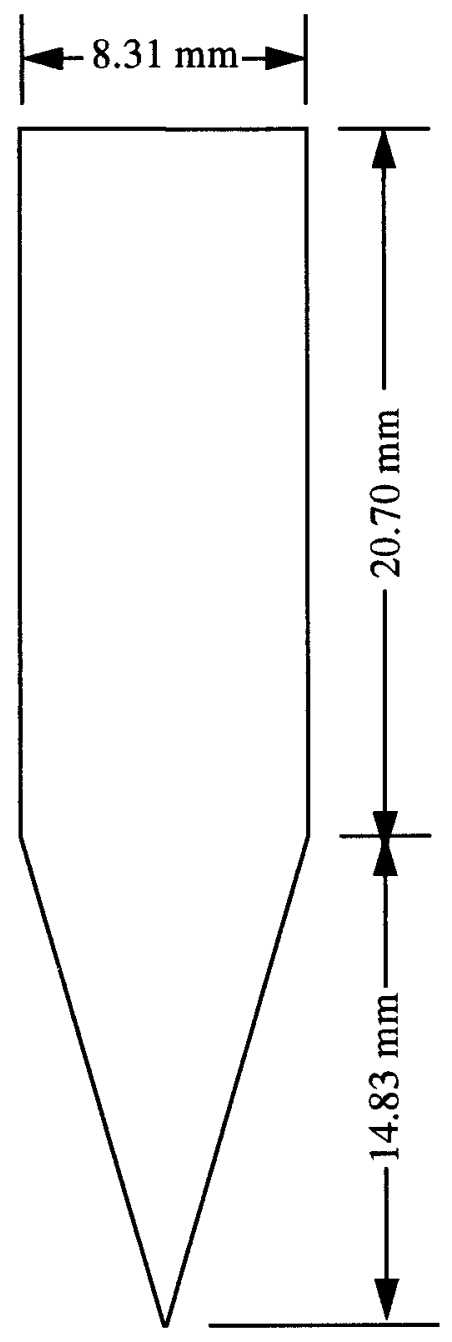

Figure 2.1. Projectile shape. 


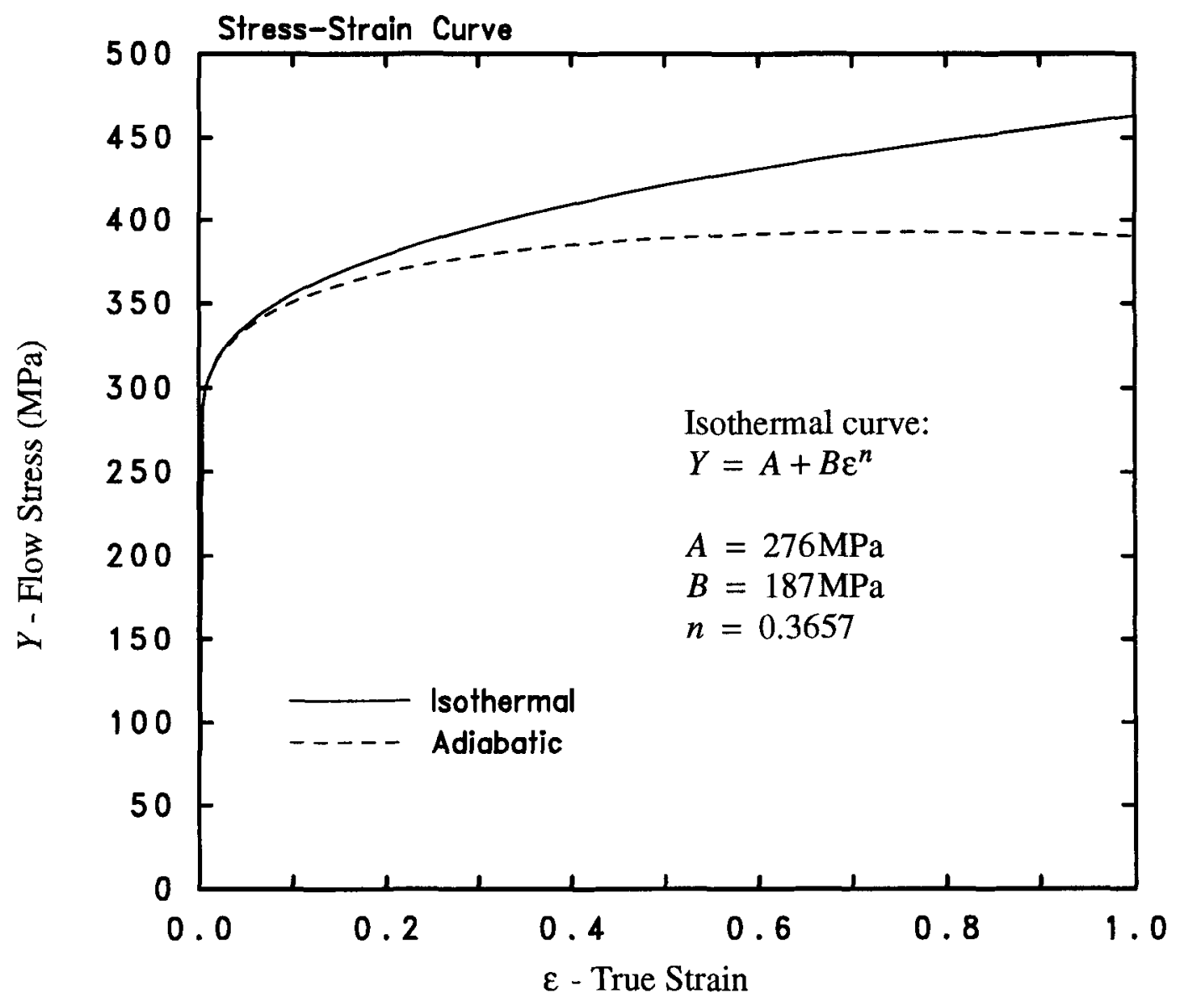

Figure 2.2. Stress-strain curves for the target material. 


,

(1)

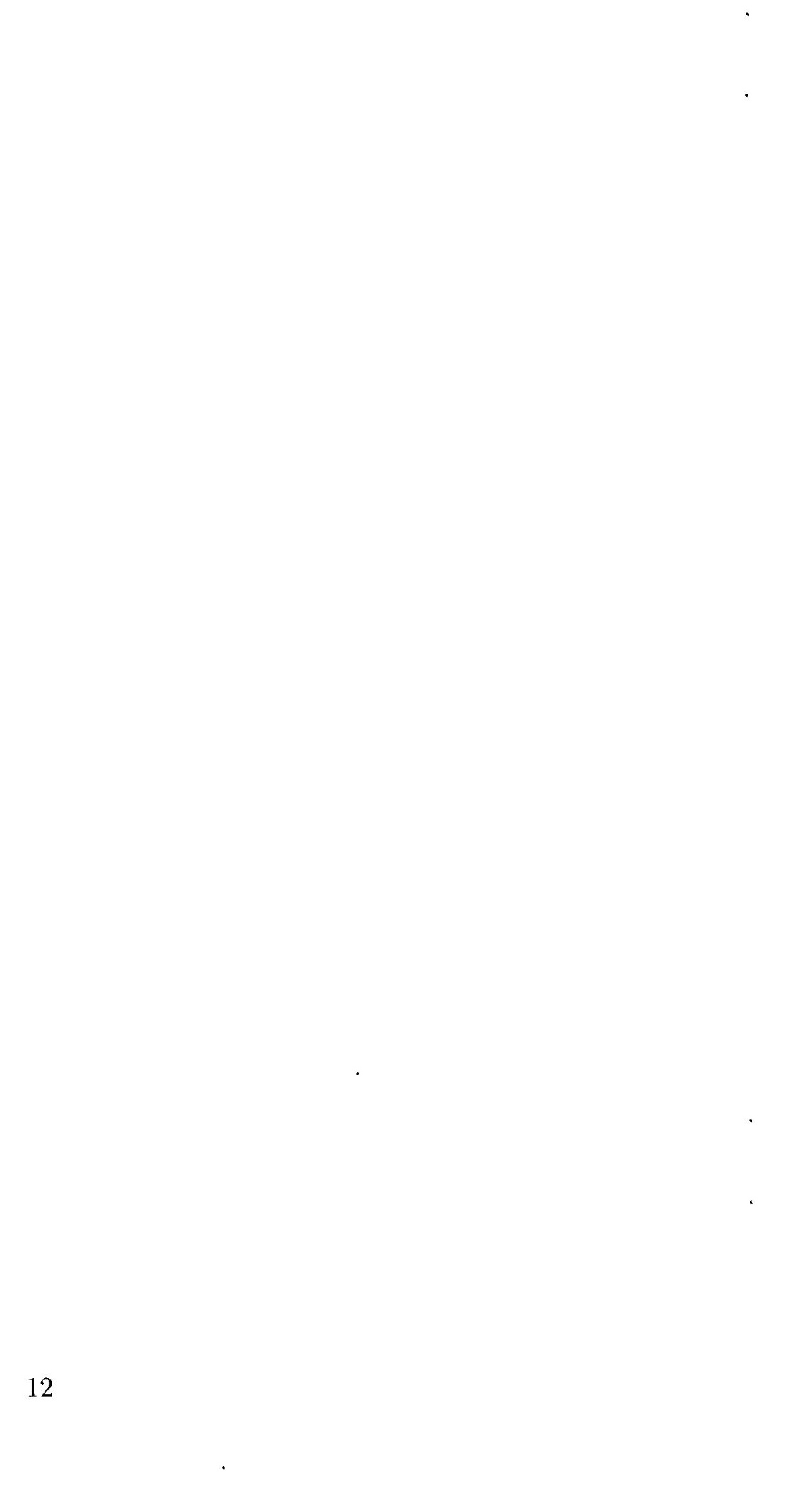
.

.

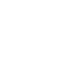




\section{Boundary Layer Algorithm}

To motivate the following discussion, let us first consider some results that CTH gives without the boundary layer algorithm when applied to the problem described in the previous section. It should be noted that CTH originally was not intended to be applied to problems involving impact of solids at such low velocities; it was intended primarily for higher velocities and stresses. There are many applications, particularly those in which erosion rather than sliding predominates, where CTH performs well without the new algorithm (see, for example, [5] and [6]). The new algorithm described here represents an expansion of the code's areas of applicability rather than a correction of any defect.

For an impact velocity of $810 \mathrm{~m} / \mathrm{s}$, Figures $3.1 \mathrm{a}, \mathrm{b}$ show the $\mathrm{CTH}$ model (without the boundary layer algorithm) at time $t=0$ and at $t=150 \mu \mathrm{s}$, at which time the projectile has essentially stopped moving. (This calculation used the MIX $=3$ option, which in this problem causes the yield stress in any mixed cell to be set to the volume weighted average of the yield stresses of the constituent materials.) In fact, according to experimental data, the projectile should perforate the target and emerge with a residual velocity of $595 \mathrm{~m} / \mathrm{s}$. Note the extensive deformation of the projectile predicted by CTH, while the experimental data indicate virtually no deformation of it at this velocity. The mesh for this calculation contained approximately 7 cells across the radius of the projectile. Further mesh refinement does not significantly improve the results.

For the same problem with the MIX=2 option, which causes the yield stress in any mixed cell to be set to zero, the code predicts a fortuitous result, which is perforation with a residual velocity of $615 \mathrm{~m} / \mathrm{s}$. The reason that this result is fortuitous is that the MIX $=2$ option has the side effect of nonphysically altering, essentially at random, the yield stresses of cells remote from the penetration event. This random weakening may be termed "numerical damage." For the same example with a different impact velocity, $513 \mathrm{~m} / \mathrm{s}$, CTH using the MIX=2 option gives the result shown in Figure 3.1c. At this lower velocity, the experimental data show that the projectile does not perforate, but CTH predicts perforation with a residual velocity of $210 \mathrm{~m} / \mathrm{s}$. The disintegration of the rear surface of the target in the calculation is not seen in the experiment. The numerical damage effect is responsible for the overprediction of residual velocity and the disintegration.

After many numerical simulations, the author concluded that merely manipulating the flow stresses in mixed cells cannot provide a good model of a sliding interface. The reason for this, as mentioned in the introduction, is that setting the flow stress to zero (or some small value) causes excessive erosion of the surface of a hard penetrator. This occurs because the penetrator material in such a mixed cell tends to be swept away along 

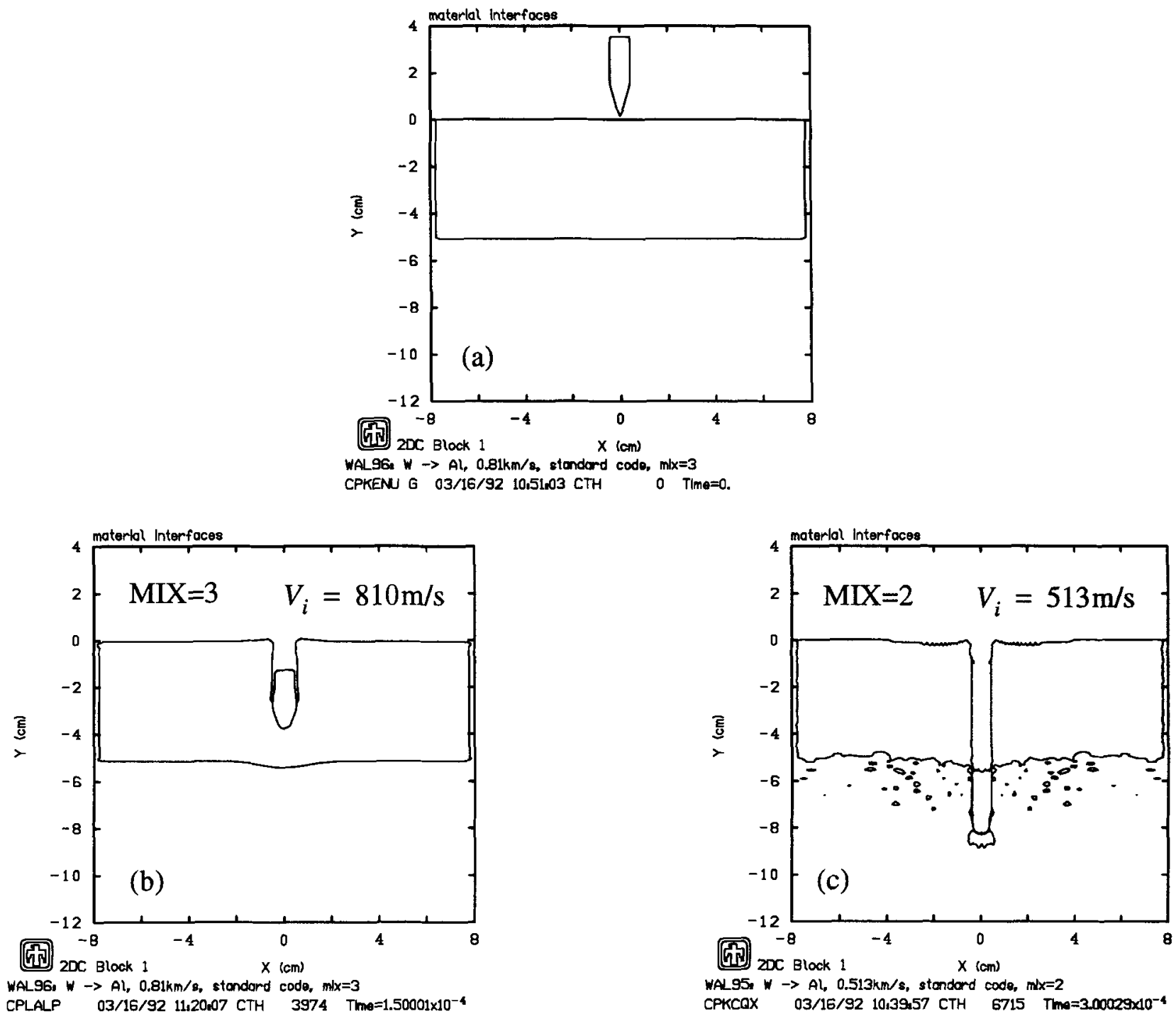

Figure 3.1. CTH results without the boundary layer algorithm. (a) initial condition, (b) result with $\mathrm{MIX}=3$, (c) result with $\mathrm{MIX}=2$. 
with the target material moving at a high relative velocity just outside the penetrator surface. These considerations motivated the development of the boundary layer algorithm described next.

We assume that two solids are in contact across a surface $S$. Let the materials on either side of $S$ be called hard (subscript $h$ ) and soft (subscript $s$ ). It is not necessary that the flow stress in the hard material actually be higher than that of the soft material, although this will usually be the case in applications. Normally, the hard material represents a penetrator and the soft material represents a target.

The essence of the boundary layer approach is that the interaction across $S$ is spread through a layer of several cell widths thickness. This is in contrast to previous approaches, in which all physical effects taking place at the surface are manifested only within the mixed cells.

Before defining the boundary layers, we first define the interface layer. This is a layer of cells about two cell widths thick that contain the actual material interface. (It is not satisfactory to define an interface just by looking for mixed cells. An example of a situation in which this would not work is an interface located exactly along a row or column of cell boundaries. In this case, there would be no mixed cells.)

To define the interface layer, we need the material volume fraction fields, $\phi_{h}$ and $\phi_{s}$. For a given cell $i, j, \phi_{h}$ is the volume of the hard material within the cell divided by the total cell volume. CTH keeps track of these quantities automatically. Next, we use central difference formulas to evaluate the vector gradients $\nabla \phi_{h}$ and $\nabla \phi_{s}$ :

$$
\left(\nabla \phi_{h_{x}}\right)_{\imath, J}=\frac{\left(\phi_{h}\right)_{\imath+1, j}-2\left(\phi_{h}\right)_{i, j}+\left(\phi_{h}\right)_{\imath-1, j}}{\Delta x^{2}}, \quad\left(\nabla \phi_{h y}\right)_{\imath, \jmath}=\frac{\left(\phi_{h}\right)_{\imath, \jmath+1}-2\left(\phi_{h}\right)_{i, j}+\left(\phi_{h}\right)_{\imath, \jmath-1}}{\Delta y^{2}},
$$

where $\Delta x$ and $\Delta y$ are the cell widths, which will be assumed constant for simplicity. $\nabla \phi_{s}$ is computed similarly.

The interface layer is defined as those cells in which both $\left|\left(\nabla \phi_{h}\right)_{r, 3}\right| \geq 0.1$ and $\left|\left(\nabla \phi_{s}\right)_{\imath, 3}\right| \geq 0.1$. Each cell in the interface layer has an effective unit normal vector $\mathbf{n}_{\imath, 3}$ associated with it, defined by

$$
\mathbf{n}_{\imath, j}=\frac{\left(\nabla \phi_{h}\right)_{\imath, j}-\left(\nabla \phi_{s}\right)_{i, j}}{\left|\left(\nabla \phi_{h}\right)_{\imath, j}-\left(\nabla \phi_{s}\right)_{\imath, j}\right|}
$$

Note that this unit vector points into the hard material. The algorithm is also shown in the flow chart in Figure 3.2, and a typical configuration is shown in Figure 3.3.

Once the interface layer is defined, we define the boundary layers. There are two boundary layers along a given interface: the hard boundary layer, which lies primarily in the hard material, and the soft boundary layer, which lies primarily in the soft material (Figure 3.4). Within the soft boundary layer, there is also a slip layer, whose purpose is 


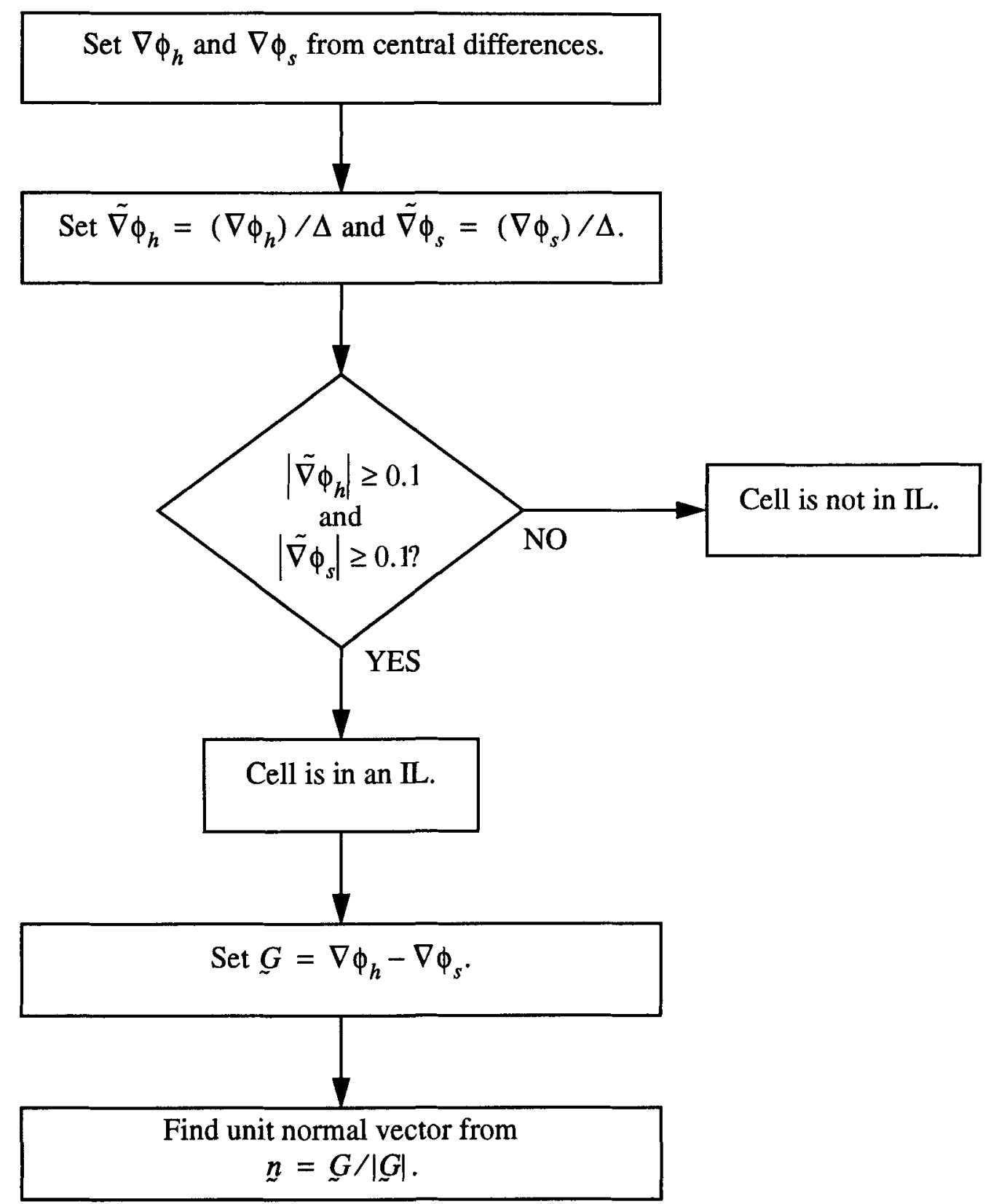

$$
\begin{aligned}
& \Delta=\text { typical cell width } \\
& \mathrm{IL}=\text { interface layer }
\end{aligned}
$$

Figure 3.2. Flow chart for the interface layer definition algorithm. 


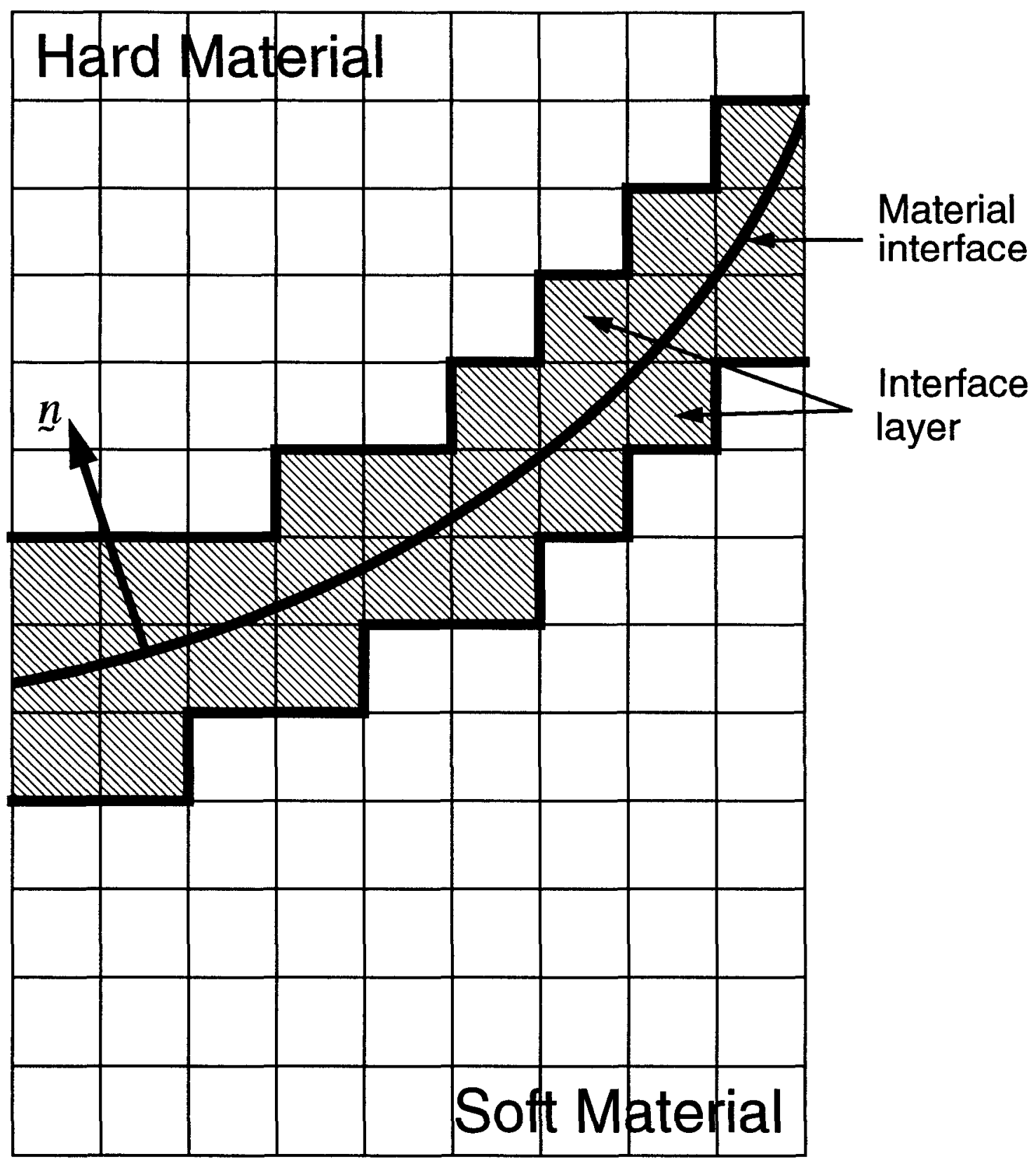

Figure 3.3. Interface layer. 
to model a frictionless sliding interface (Figure 3.5). Processes taking place within these layers model all the physical interactions across the material interface. Figure 3.6 shows a representation of the physical ideas underlying the boundary layer approach. The flow stress $Y$ goes to zero in the slip layer, modeling a frictionless sliding interface.

The algorithm for defining these layers is summarized in the flow chart in Figure 3.7. In simplified terms, a cell is in some boundary layer if its center is within a predefined distance $w_{b l}$ of the center of some cell in an interface layer. It is in the soft boundary layer if it is also at least $99 \%$ filled with the soft material; otherwise it is in the hard boundary layer. Note that according to this algorithm, the mixed cells along the material interface are almost always in the hard boundary layer.

The value of $w_{b l}$ would normally be between 1.4 and 5 cell widths. If it is set to less than 1.4 cell widths, then there can be cases in which an interface layer has no continuous boundary layer next to it at all. If it is set to more than 5 cell widths, then errors tend to be introduced due to changes in the effective shape of a penetrator. (See Section 5.)

The cells in the slip layer are found as follows. If a cell is in the soft boundary layer and its center is also within a predefined distance $w_{s l}$ of the center of some cell in the interface layer, then it is within the slip layer (we assume $0<w_{s l} \leq w_{b l}$ ). $w_{b l}$ will be called the boundary layer thickness and $w_{s l}$ will be called the slip layer thickness.

To model a frictionless sliding interface, cells within the slip layer have their flow stresses (and therefore their deviatoric stress tensors) set to zero. These quantities are set to zero even if friction is present. This is done because the frictional forces are not included through the deviatoric stresses. Instead, they are included as body forces within the cells within the boundary layers, including the slip layer. The means of computing these body forces are described next.

For each cell $i, j$ in one of the boundary layers, we first find the average velocity vector among cells with $\phi_{h} \geq 0.9$ located within a distance $r_{V}$ of $i, j$ (Figure 3.8). $r_{V}$ is a constant that, in the current implementation, is set to $r_{V}=4 w_{b l}$. This value is intentionally large compared to the boundary layer thickness so that small local fluctuations in velocity will tend to be averaged out. The average velocity of the hard material near $i, j$ found in this way will be called $\mathbf{V}_{\text {hard }}$. Similarly, we compute an average velocity of the soft material $\mathbf{V}_{\text {soft }}$. However, in computing $\mathbf{V}_{\text {soft }}$, we exclude cells in the slip layer from the averaging process because their velocities do not accurately reflect the bulk motion of the material. Next, we evaluate the relative velocity vector of hard and soft material near $i, j$ from

$$
\overline{\mathbf{V}}=\mathbf{V}_{\text {hard }}-\mathbf{V}_{\text {soft }} .
$$

Recall that for each cell in either boundary layer, we computed an effective unit vector $\mathbf{n}$ normal to the interface. For a given cell $i, j$, we now evaluate $\overline{\mathbf{n}}$, the average of these unit vectors for cells within a distance $r_{n} . r_{n}$ is a constant currently set to $2 w_{b l}$. 


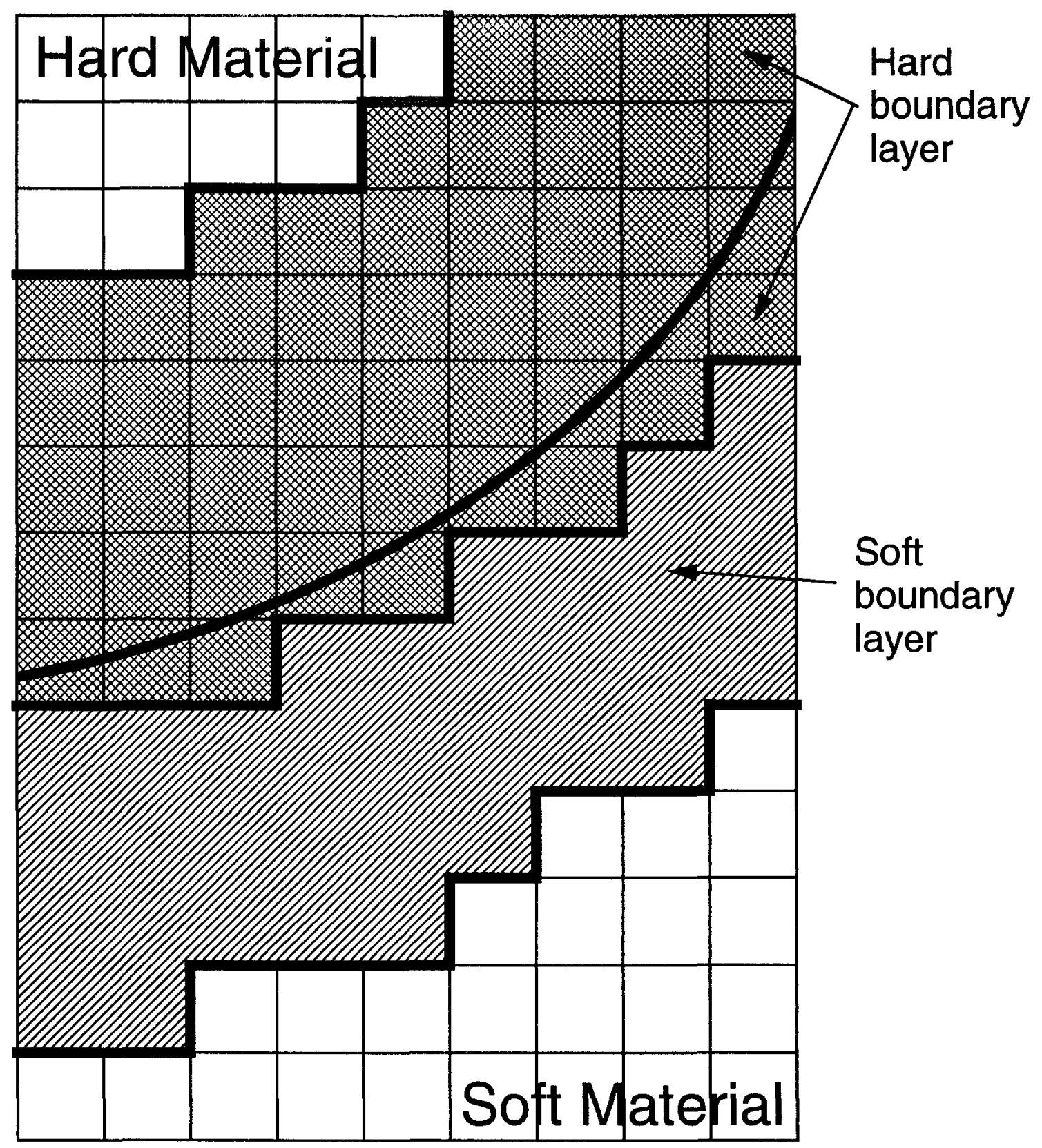

Figure 3.4. Hard and soft boundary layers. 


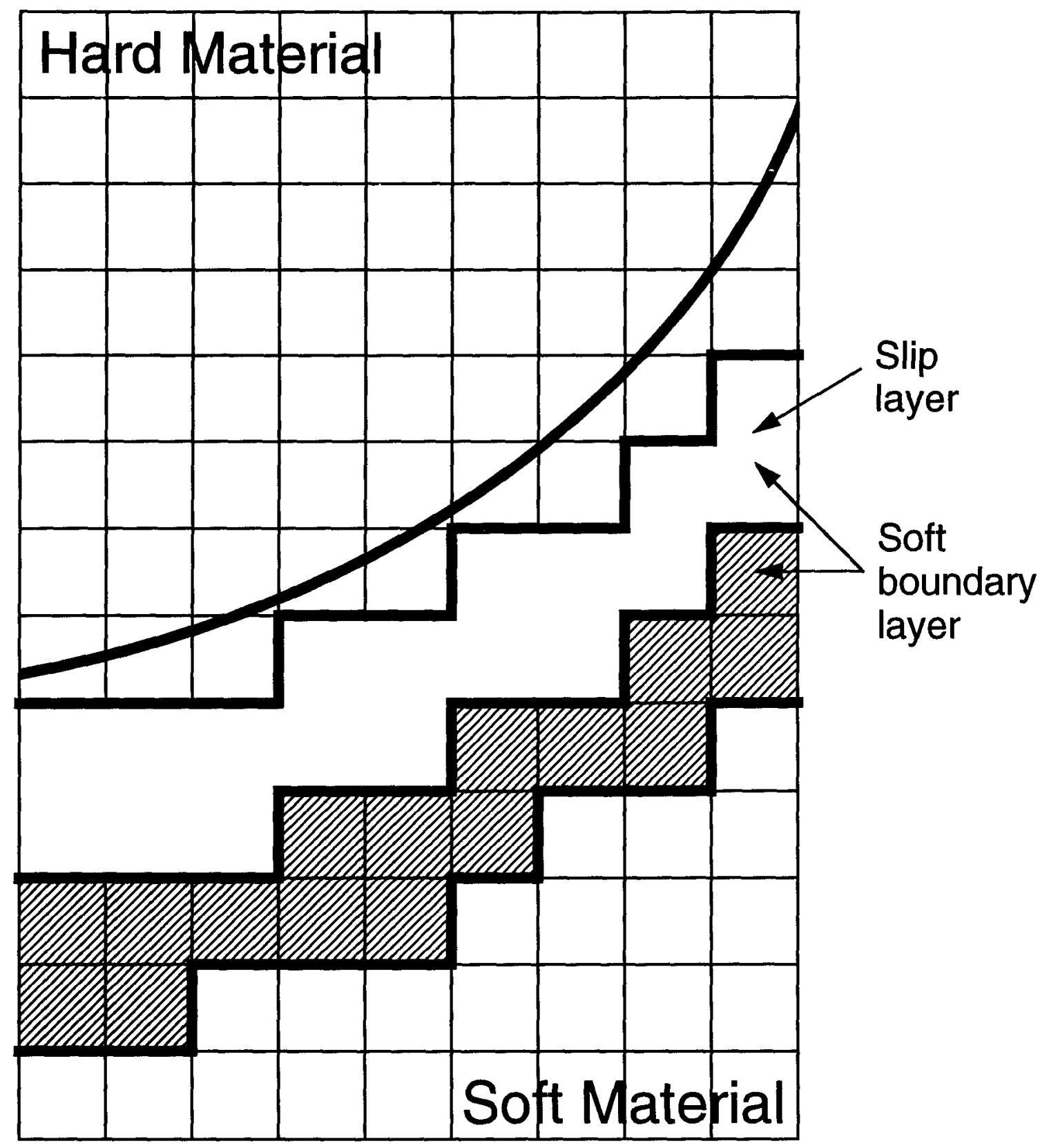

Figure 3.5. Structure of the soft boundary layer. 


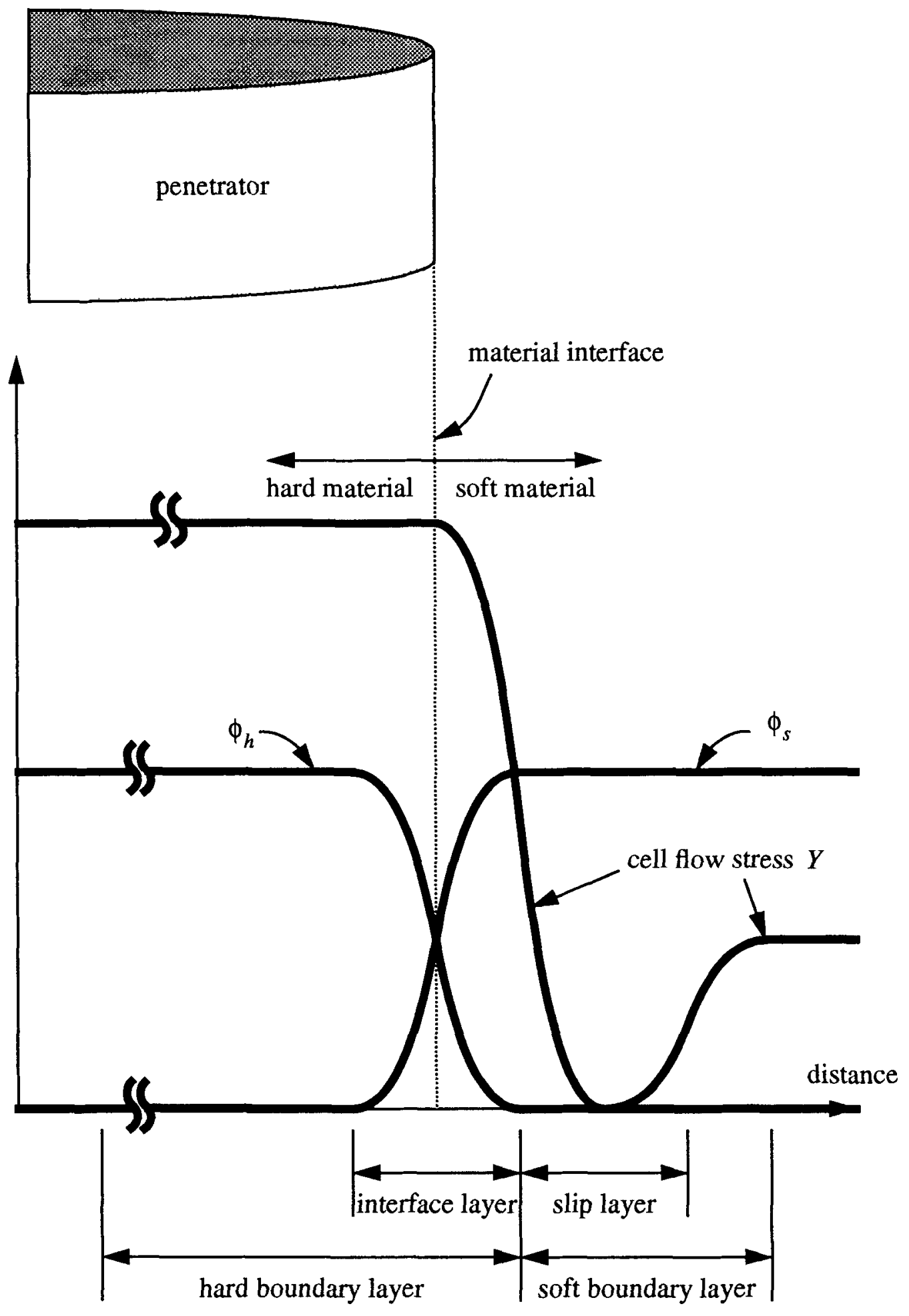

Figure 3.6. Placement of layers with respect to the material interface. 


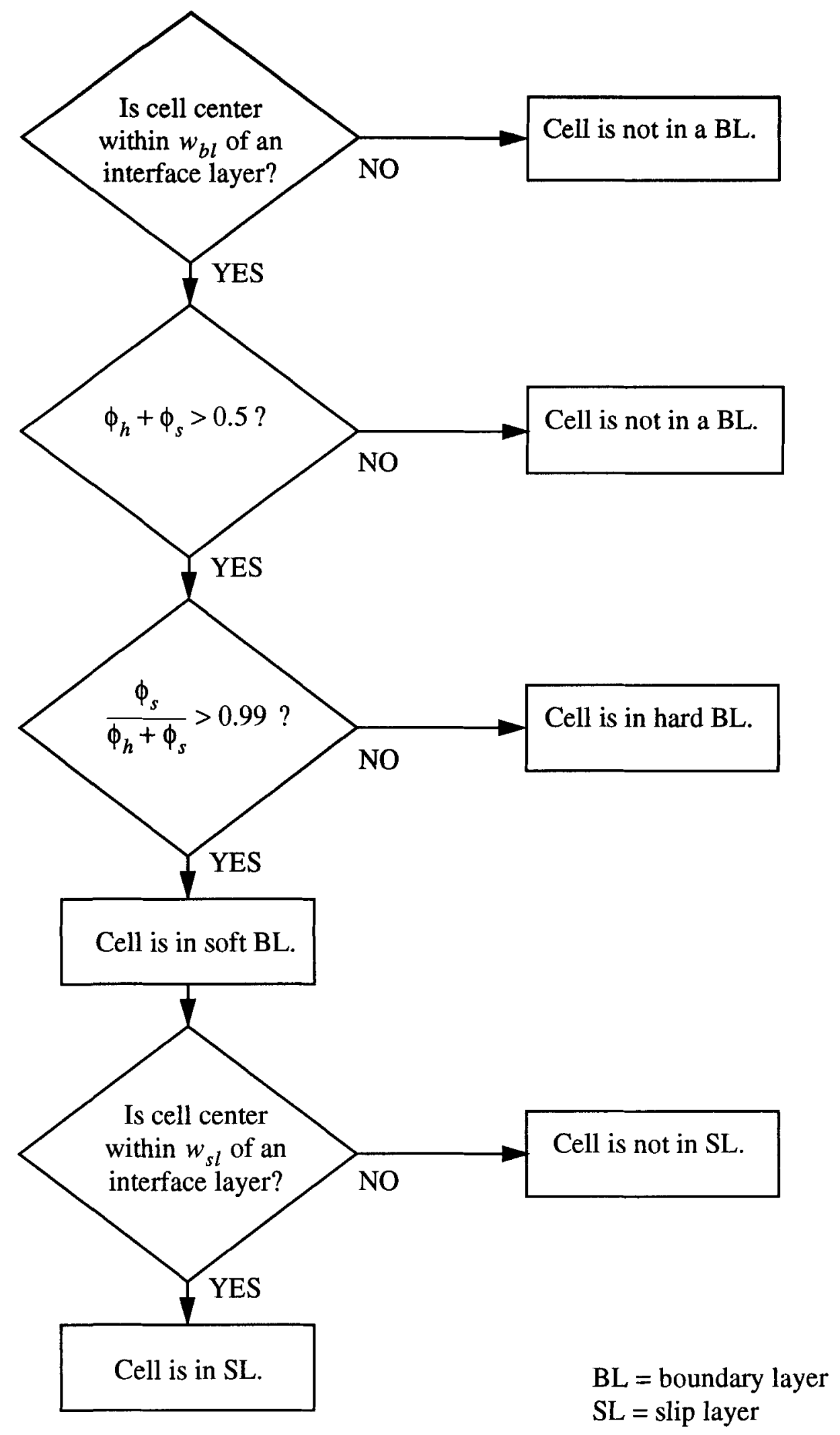

Figure 3.7. Flow chart for the boundary layer definition algorithm. 
The only purpose for computing the local relative velocity of the materials is as a means for computing $u$, the unit vector in the direction of the friction force on the soft layer. This is not simply in the direction of $\mathbf{V}$, because the material interface may be moving in a direction normal to itself; hence $\mathbf{V}$ may not be tangential to the surface. For $\mathbf{u}$, we seek a unit vector tangential to the surface. Using the right-hand rule for vector cross products, this is supplied by

$$
\mathbf{u}=\frac{(\overline{\mathbf{n}} \times \overline{\mathbf{V}}) \times \overline{\mathbf{n}}}{|(\overline{\mathbf{n}} \times \overline{\mathbf{V}}) \times \overline{\mathbf{n}}|}
$$

Figure 3.9 illustrates the calculation of the vector $\mathbf{u}$.

The shear traction $\mathbf{t}_{f}$ due to friction on a surface is computed from

$$
\mathbf{t}_{f}= \pm f \min \{0, \overline{\mathbf{n}} \cdot(\overline{\mathbf{T}} \overline{\mathbf{n}})\} \mathbf{u}
$$

where $\overline{\mathbf{T}}$ is the Cauchy stress tensor and $f$ is the friction coefficient. The scalar quantity $\overline{\mathbf{n}} \cdot(\overline{\mathbf{T}} \overline{\mathbf{n}})$ is the normal traction, which must be compressive (negative) in order for the traction due to friction to be nonzero. For a cell $i, j$ in either boundary layer, $\overline{\mathbf{T}}$ is obtained by averaging the values of the Cauchy stress $\mathbf{T}$ among cells within a radius $r_{T}$ of $i, j$, where $r_{T}$ is a constant currently set to $4 w_{b l}$. The sign in (3.5) is negative (-) if $i, j$ is in the soft layer and positive (+) if it is in the hard layer.

Friction forces are applied only to cells that are in one of the boundary layers but not in the interface layer. They are not applied in the interace layer because, in general, the interface layer contains some mixture of materials, and the time integration algorithm has no means of applying body forces separately to materials within a cell. Once the local shear traction due to friction $\mathbf{t}_{f}$ is computed for a cell $i, j$ in one of the boundary layers, it is converted to a body force density $b_{f}$ (units of force/volume) for purposes of the momentum balance calculation. This is found from

$$
\left(\mathbf{b}_{f}\right)_{i, j}=\left(\mathbf{t}_{f}\right)_{i, j} / w_{b l} .
$$

The calculation in (3.6) assumes, for the case of square cells, that each cell represents the same total volume. This is true for calculations in rectangular coordinates, but for cylindrical coordinates we must make a correction. This correction accounts for the fact that even if $\Delta x$ and $\Delta y$ are constant and equal, cells with different values of $x_{i, j}$ (where $x$ is the radial coordinate) contain different total volumes. Let $i$ and $j$ be fixed, and assume that cell $i, j$ is in a boundary layer. Let $\bar{x}_{i n t}$ be the average radial coordinate of all interface layer cells that are within a distance $r_{T}$ of cell $i, j$. The total volume of cell $i, j$ is approximately $\mathcal{V}_{i, j}=\pi \Delta x \Delta y x_{i, j}$. If the same cell were centered at the interface, its volume would be approximately $\pi \Delta x \Delta y \bar{x}_{i n t}$. Therefore, to make the total frictional force to be applied to cell $i, j$ equal the value it would have had if it were on the interface, we must multiply $\left(\mathbf{b}_{f}\right)_{i, j}$ by $\bar{x}_{i n t} / x_{i, j}$. 


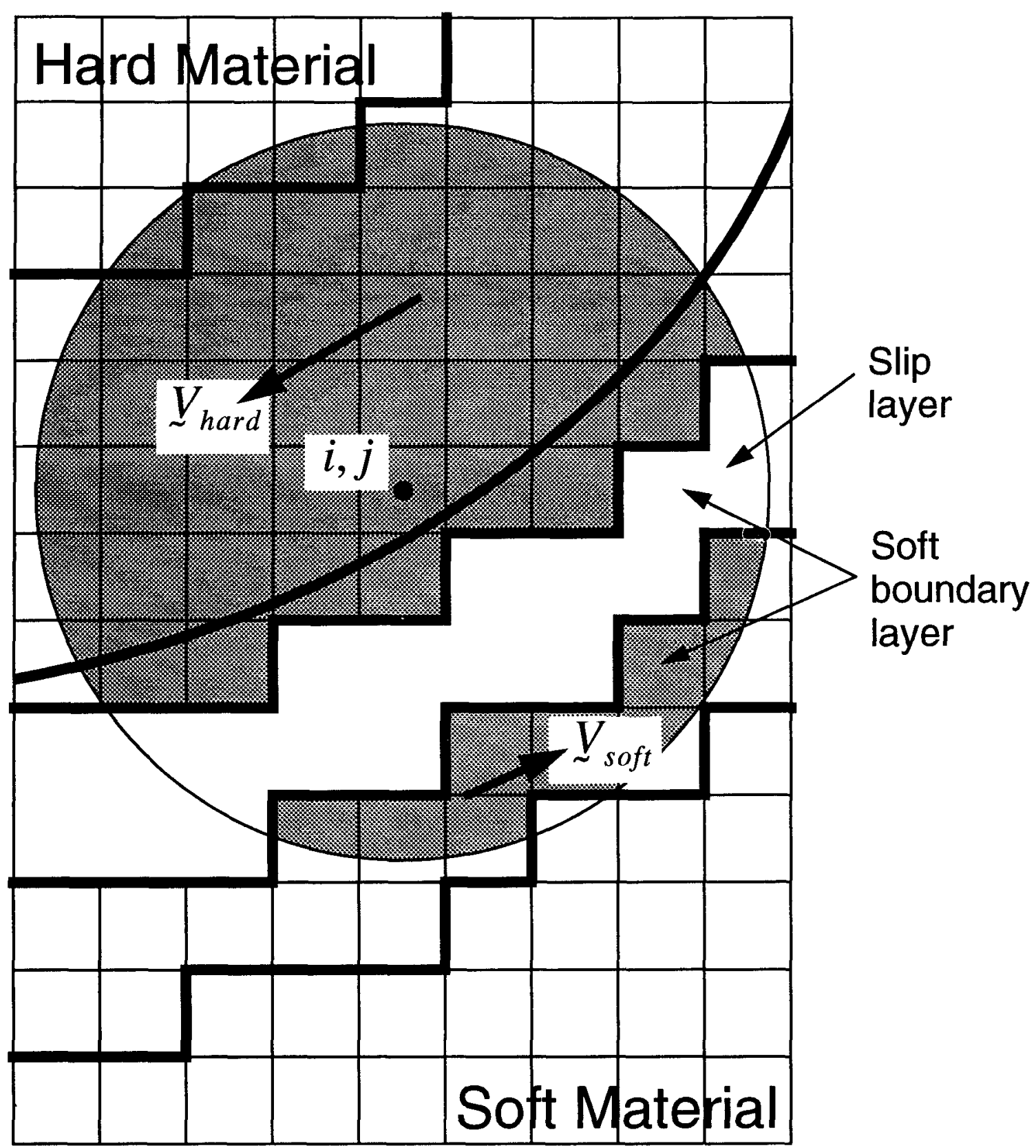

Figure 3.8. Evaluation of boundary layer average velocities. 


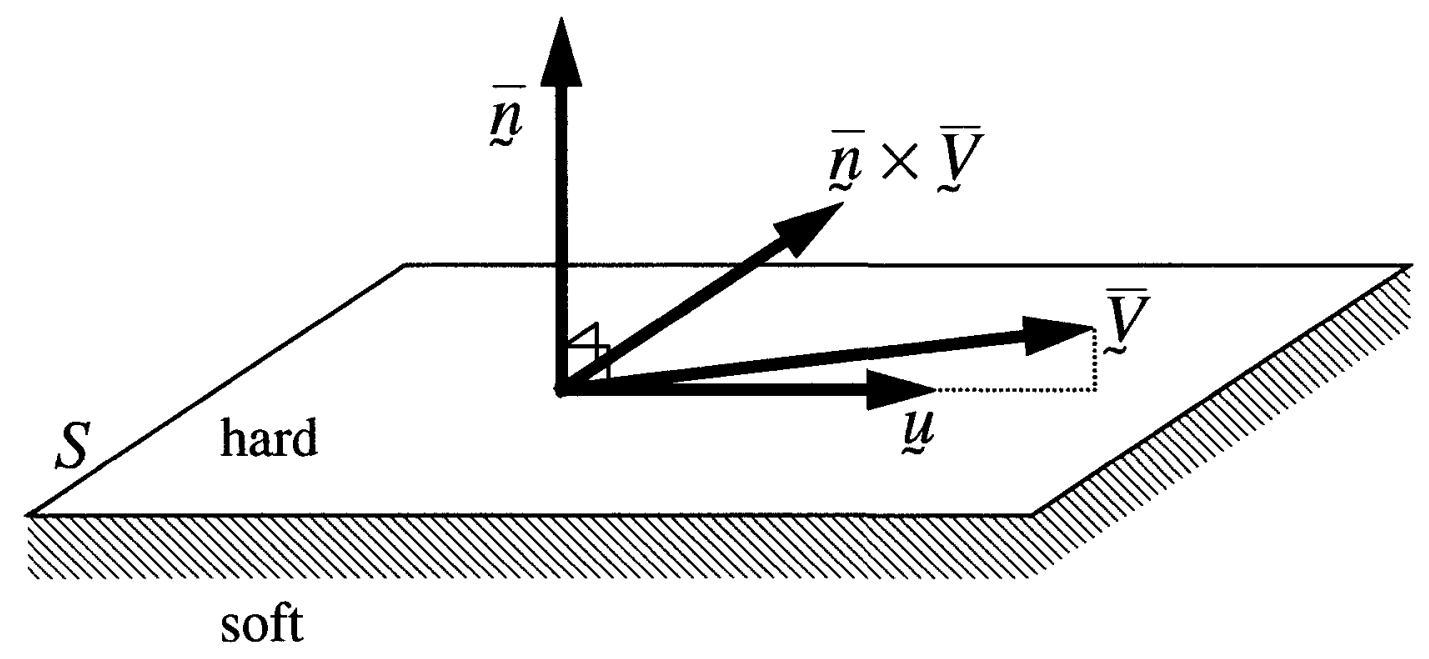

Figure 3.9. Calculation of the direction vector $\underset{\sim}{u}$ for frictional forces. 
The body force density appears in the momentum balance equation in the form

$$
\rho \mathbf{a}=\nabla \cdot \mathbf{T}+\mathbf{b}_{f}
$$

where $\rho$ is density and $\mathbf{a}$ is acceleration. The frictional term is easily included in the discretized form of the momentum balance. Figure 4.8 in the next section shows a typical distribution of frictional body forces computed according to the algorithm described previously.

At any given time step in a calculation, there will be some error in this friction computation due to the mesh coarseness. For example, if $w_{b l}$ is set on input to 2.5 times a typical cell width, then the number of cells in which friction is computed in the hard layer at some location along the material interface might fluctuate between 2 and 3, and occasionally even 1 and 4 . At locations along the material interface where there are 1 or 2 such cells, too little friction force will be added, and where there are 3 or 4 , too much will be added at a given time step. However, over many time steps, these errors average out and the net force added will be close to the correct value.

Mixed cells along the material interface have their flow stresses set to the maximum materiai flow stress among their constituents. This is done in order to prevent nonphysical erosion of the surface of a hard material due to dilution of its flow stress in a mixed cell. This is the only aspect of the algorithm that involves direct maniputation of the properties of mixed cells. 


\section{Numerical Simulations}

This section presents results of CTH simulations of the perforation problem specified in Section 2 using the boundary layer algorithm discussed in Section 3. Two meshes were used to help assess the sensitivity of the results to cell spacing. The finer of the two meshes had $\Delta x=\Delta y=0.04$ in the vicinity of the path of the penetrator. The coarser had $\Delta x=\Delta y=0.06$ in this path. Geometric spacing was used in the radial direction. In the finer mesh, there were about 10 cells across the radius of the penetrator, and in the coarser mesh there were about 7 . The target radius was $7.8 \mathrm{~cm}$, and the results were very insensitive to this value. In the $\Delta x=0.04$ calculations, the input parameters for the boundary layer algorithm were as follows: $w_{b l}=0.12, w_{s l}=0.06$. In the $\Delta x=0.06$ calculations, they were $w_{b l}=0.18, w_{s l}=0.09$. Other parameters used in the boundary layer algorithm, such as $r_{V}$, were set based on the input parameters as described in the previous section.

Results of the calculations with the $\Delta x=0.04$ mesh, both without friction and with a friction coefficient of $f=0.05$, are shown in Figure 4.1. This graph shows residual velocity of the penetrator as a function of impact velocity. The experimental data from [3] are also shown for impact velocities above the ballistic limit. The errors in the experimental measurements of velocity are less than $1 \%$. All the curves were fitted to functions of the form $V_{r}=A \sqrt{V_{i}^{2}-B^{2}}$, where $V_{r}$ and $V_{i}$ are the residual and impact velocities, and $A$ and $B$ are constants. ( $B$ represents the ballistic limit.) This general form is suggested by analytical models of penetration [3].

Similar results are shown for the $\Delta x=0.06$ mesh in Figure 4.2. The results for the frictionless case are shown in Figure 4.3 for both meshes.

Figure 4.4 shows the shapes of the penetrator and target after $140 \mu$ s for the case $V_{i}=810 \mathrm{~m} / \mathrm{s}$ for the two meshes. Close-up views of the penetrator as it emerges are shown in Figure 4.5 for the same two calculations. Note the improved retention of the penetrator shape compared with the result shown in Figure 3.1. Also note that some target material tends to adhere to the surface of the penetrator. The reason for this adherence is that some target material becomes trapped between the slip layer (where most of the sliding motion occurs) and the surface of the penetrator. This trapped material has nonzero flow stress, and, in the absence of friction, it is not subjected to any significant shear tractions that would tend to pull it away. Therefore, it clings to the penetrator surface. This phenomenon does not appear to cause any significant problems for most applications.

Contours of equivalent plastic strain for the frictionless calculation in the $\Delta x=0.04$ 


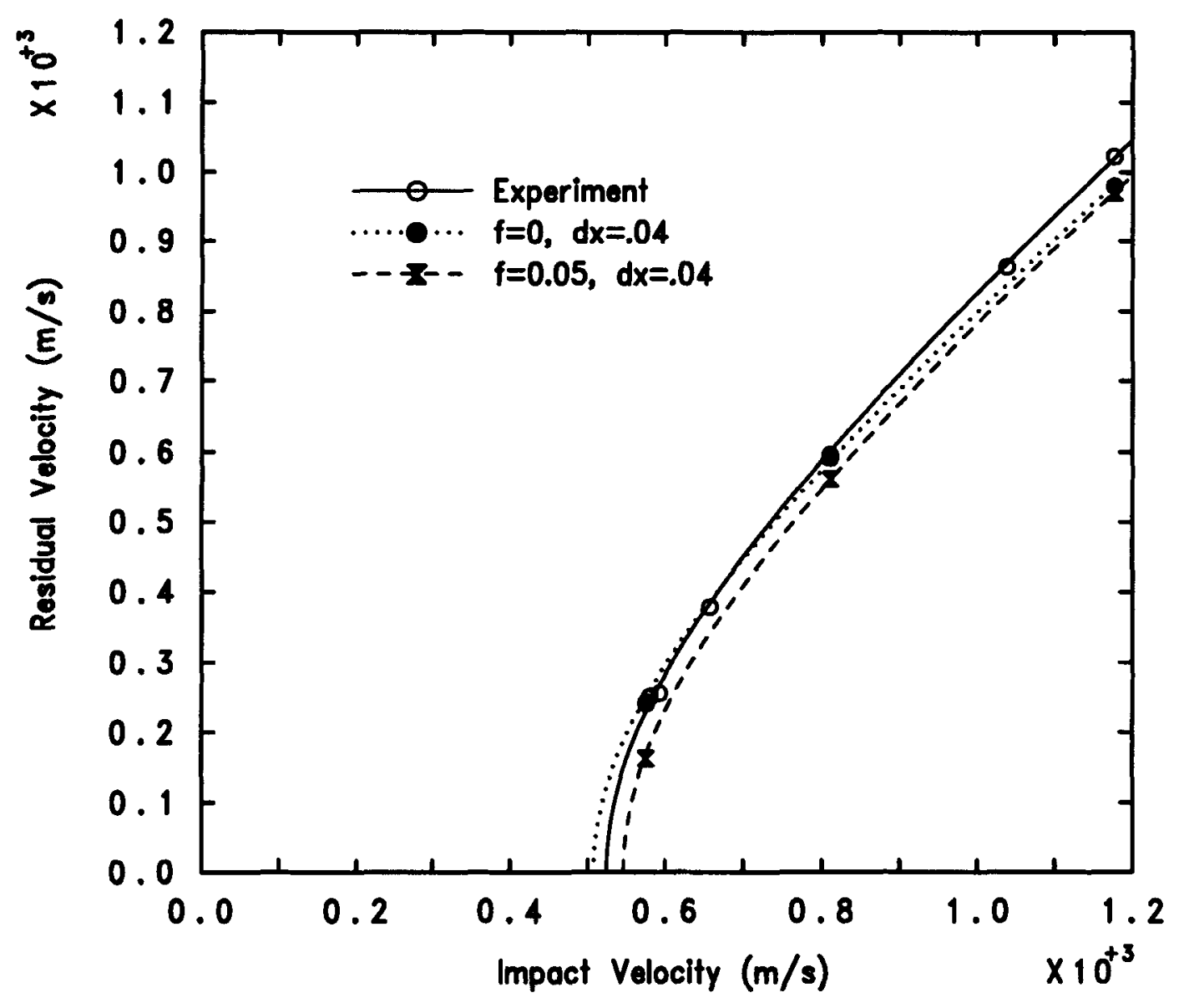

Figure 4.1. CTH results for the finely-zoned mesh with and wthout friction. 


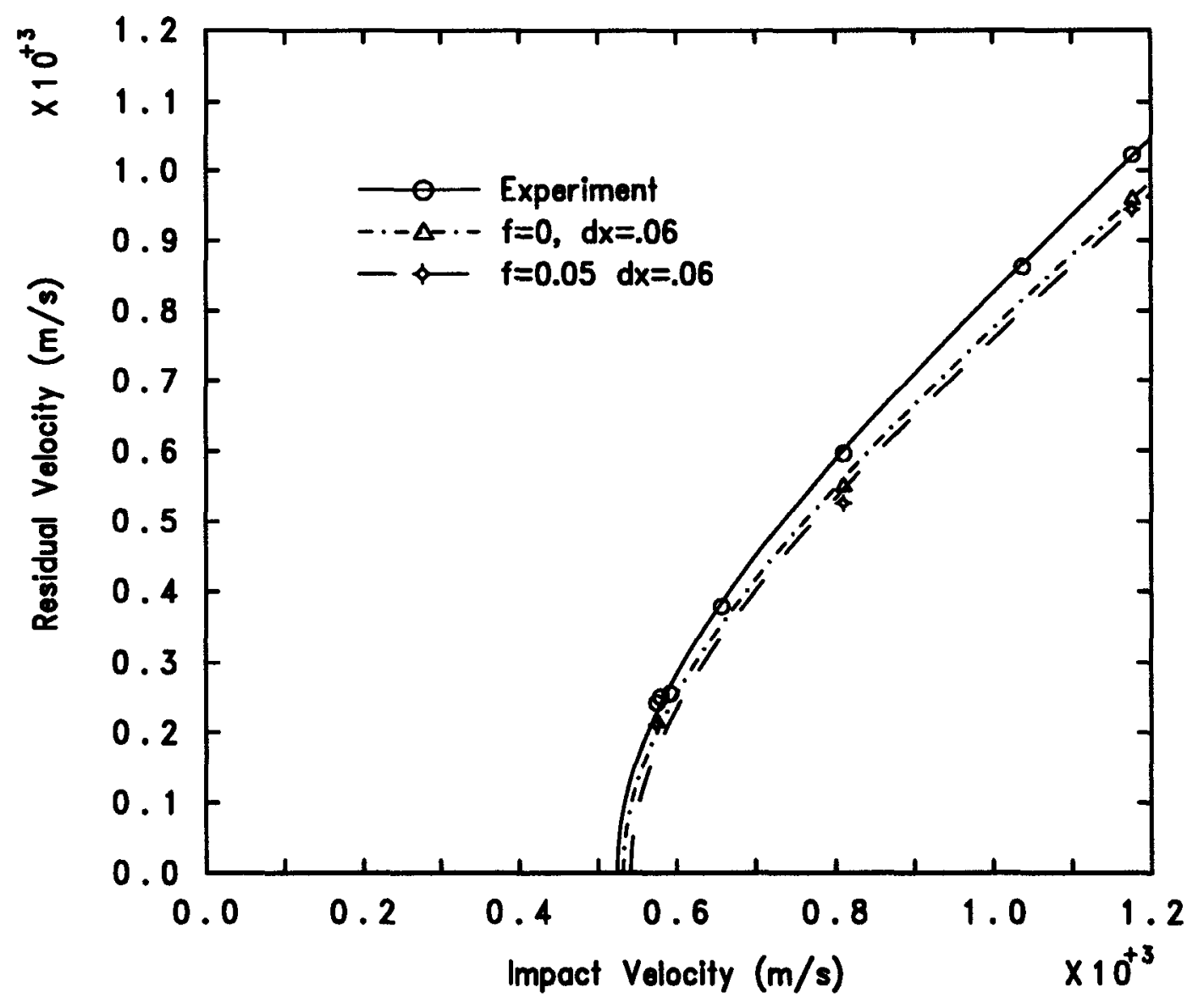

Figure 4.2. CTH results for the coarsely-zoned mesh with and whout friction. 


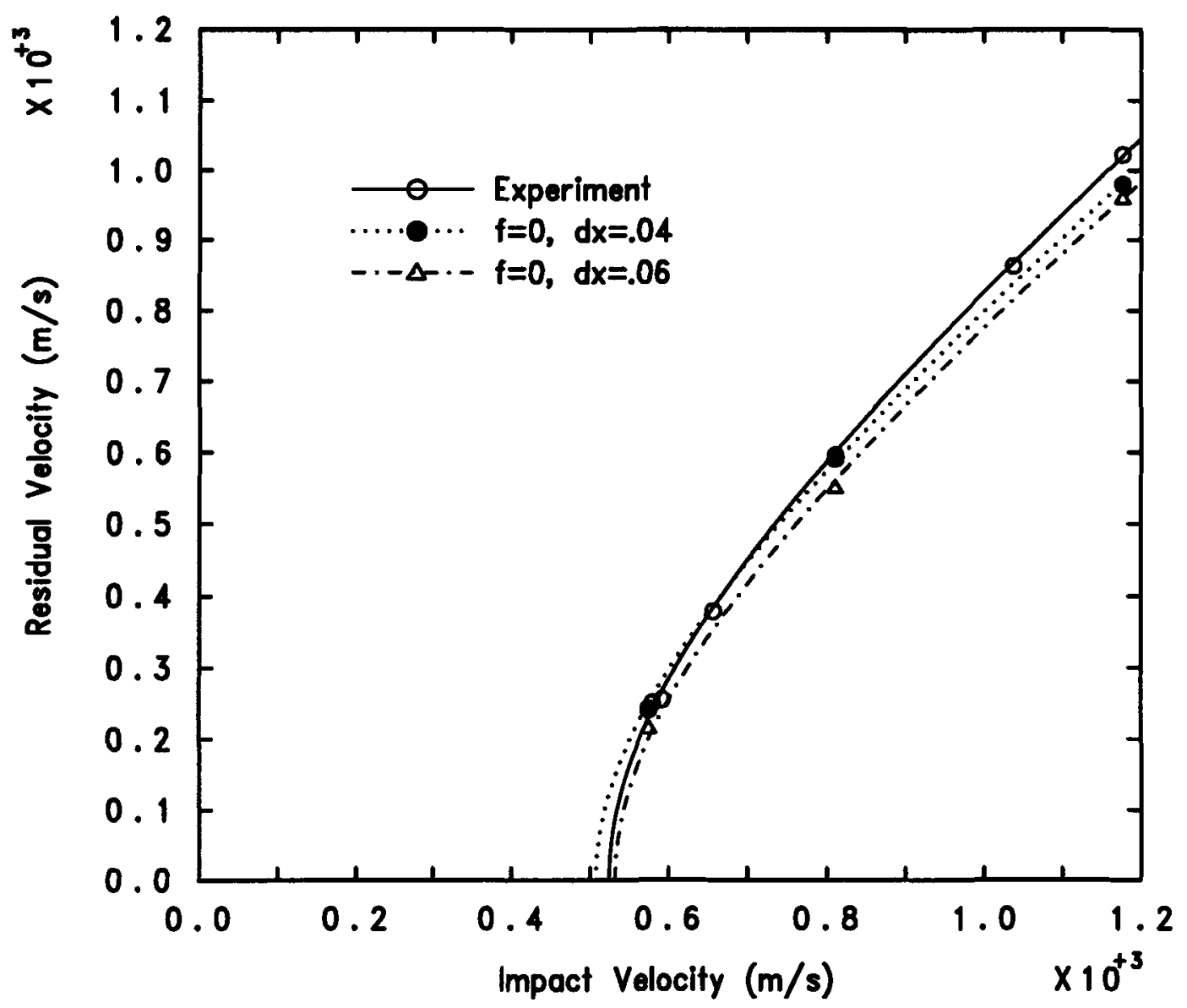

Figure 4.3. Comparison of frictionless results for the two meshes. 

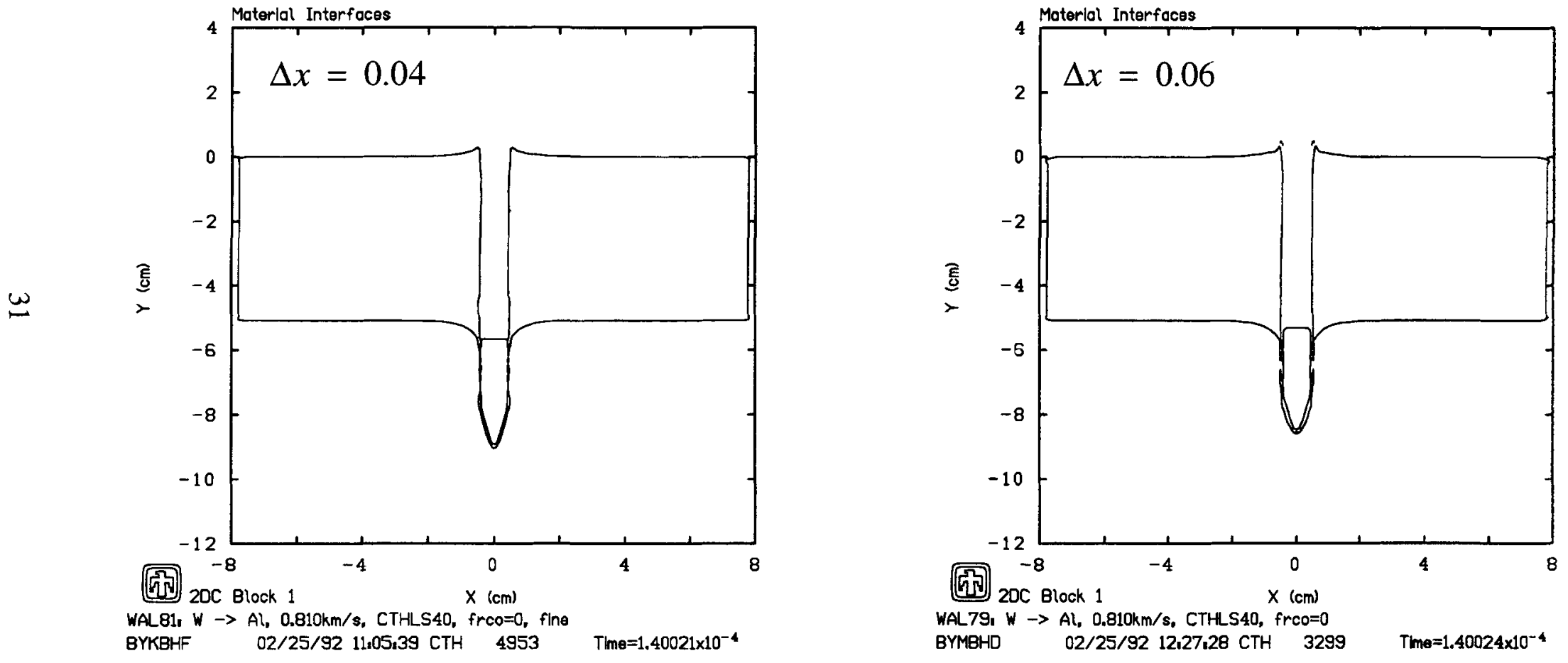

Figure 4.4. Comparison of frictionless calculations in the two meshes for an impact velocity of $810 \mathrm{~m} / \mathrm{s}$. 

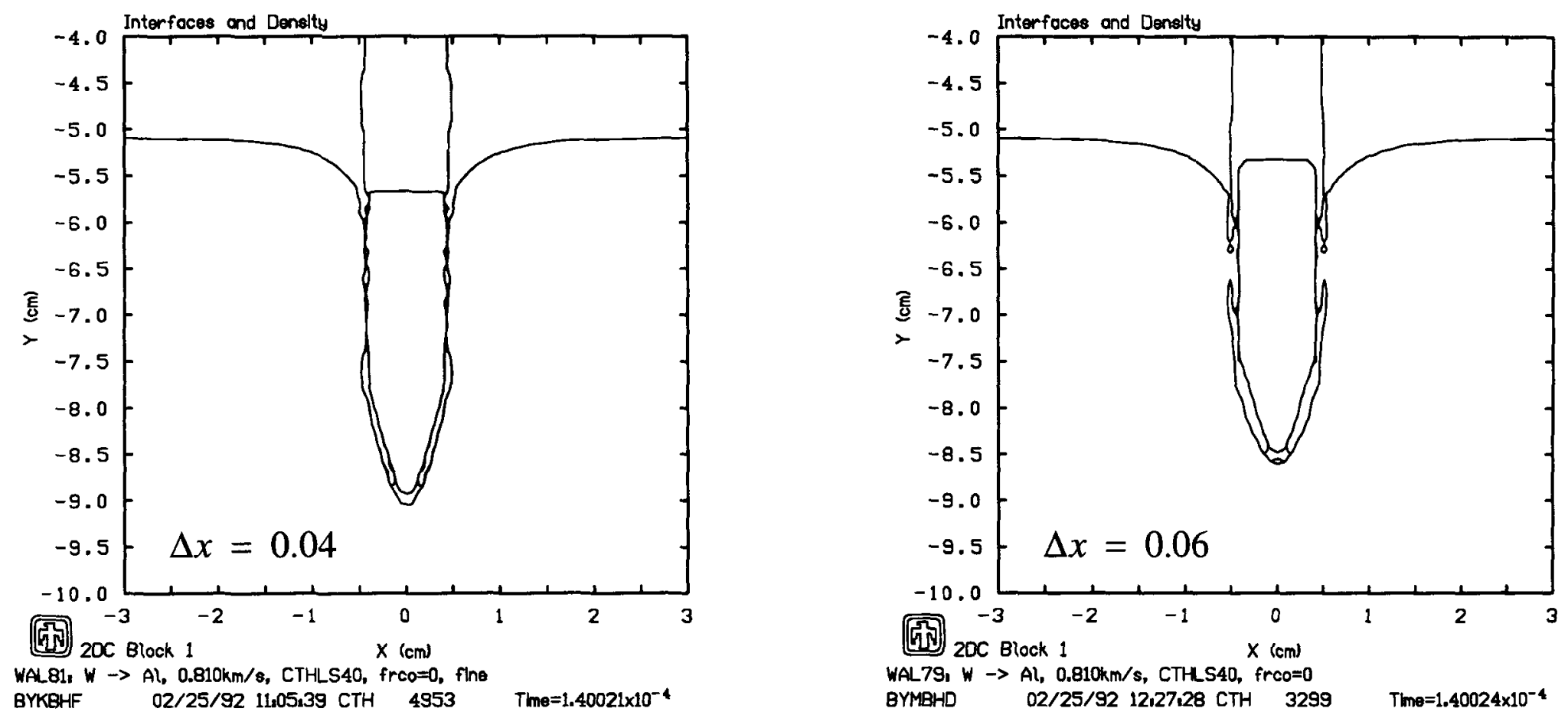

Figure 4.5. Details of emerging penetrator shapes, frictionless, impact velocity $810 \mathrm{~m} / \mathrm{s}$. 
mesh are shown in Figure 4.6 for four separate times. The development of the equivalent plastic strain field appears to be reasonable physically, but no quantitative assessment of this has been undertaken.

Figure 4.7 shows the residual velocities for an impact velocity of $810 \mathrm{~m} / \mathrm{s}$ for a few variations of the base case, which is the frictionless calculation with the $\Delta x=0.06$ mesh. Note the difference in scale from the previous graphs. The point labeled "damage model" is the same as the base case but uses the Johnson-Cook fracture model [7] for the target material. The parameters for this particular material were not available, so the calculation was done with parameters for 2024-T351 aluminum [8]. The point labeled "friction" is the same as the base case but with a friction coefficient of 0.05 . The point labeled "thick BL + friction" also used $f=0.05$ but had boundary layer and slip layer thicknesses 50 percent greater than the other calculations shown in this figure. The "no thermal softening" calculation was the same as the base case but with no temperaturedependence of the flow stress. In short, none of these variations resulted in more than a 5 percent difference in residual velocity.

Figure 4.8 shows a typical distribution of frictional body forces. The forces inside the penetrator are directed upward and outward, while those in the target are directed downward and inward. The left half of the figure shows the $y$-component of the body force, and the right half shows the $x$-component. Note that the forces are confined to the boundary layers and are absent in the interface layer. From the shading, one can see that the magnitude of the body force tends to be greater nearer the tip of the penetrator than the tail. This occurs because the hydrostatic pressure, as well as the other stresses giving rise to normal traction along the interface, tend to be larger there, thus increasing the frictional force.

Figure 4.9 shows the effect of modeling the target material using the Johnson-Cook fracture model as described previously, using the parameters for 2024-T351 aluminum. This figure compares the calculations for an impact velocity of $810 \mathrm{~m} / \mathrm{s}$ with and without the fracture model at $150 \mu \mathrm{s}$. The shading represents the damage variable in the model, which varies from 0 to 1 . Although the effect on exit velocity is small, the calculation with the fracture model shows a widening of the exit hole, which suggests an exit crater. The predicted cratering is less pronounced when the parameters for 6061-T6 aluminum, a tougher material, are used instead of those for 2024-T351. The experimental data [3] do not show exit cratering except to a slight extent when smaller plate thicknesses are used. However, the calculation with the fracture model is interesting because exit cratering is known to occur with many less ductile materials, suggesting that CTH might, with further development, be useful in predicting this effect. 

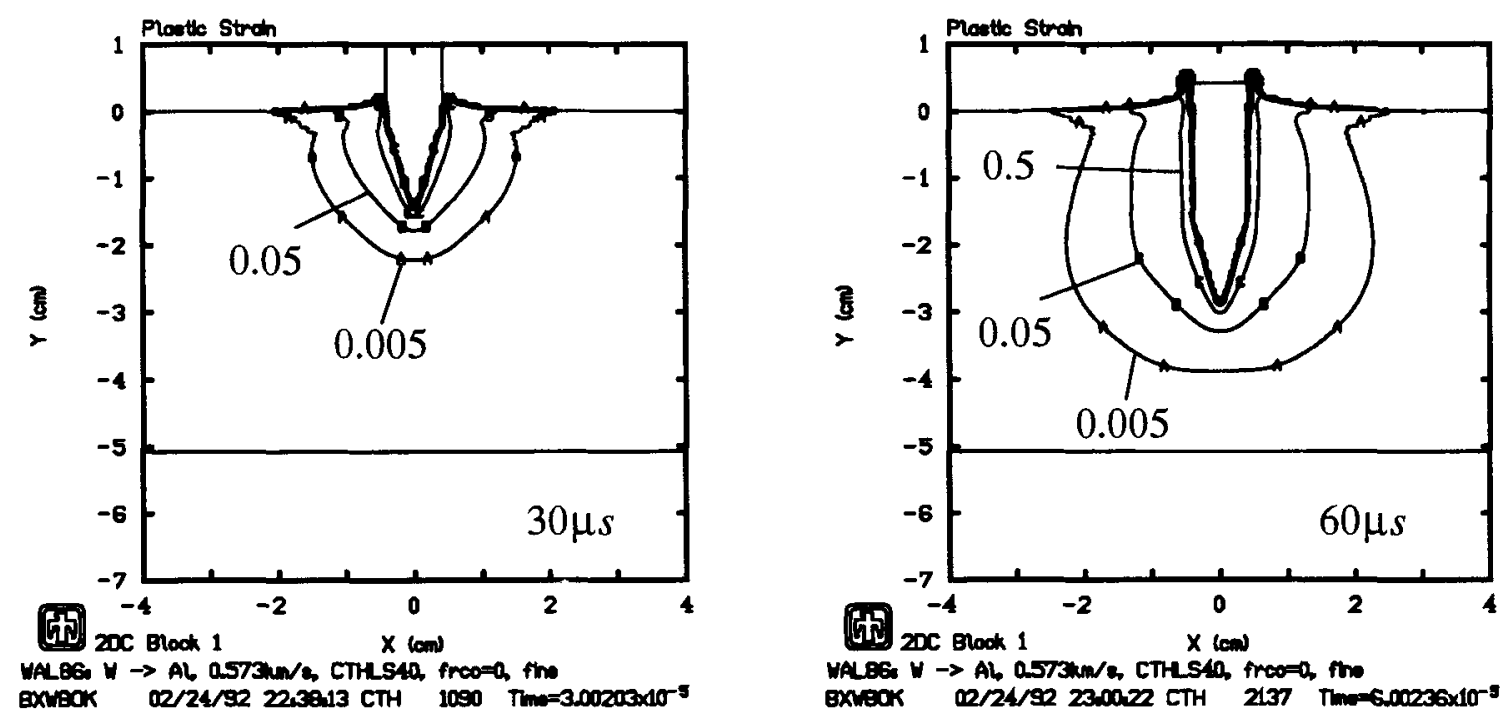

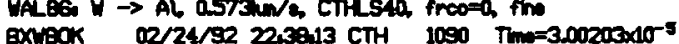
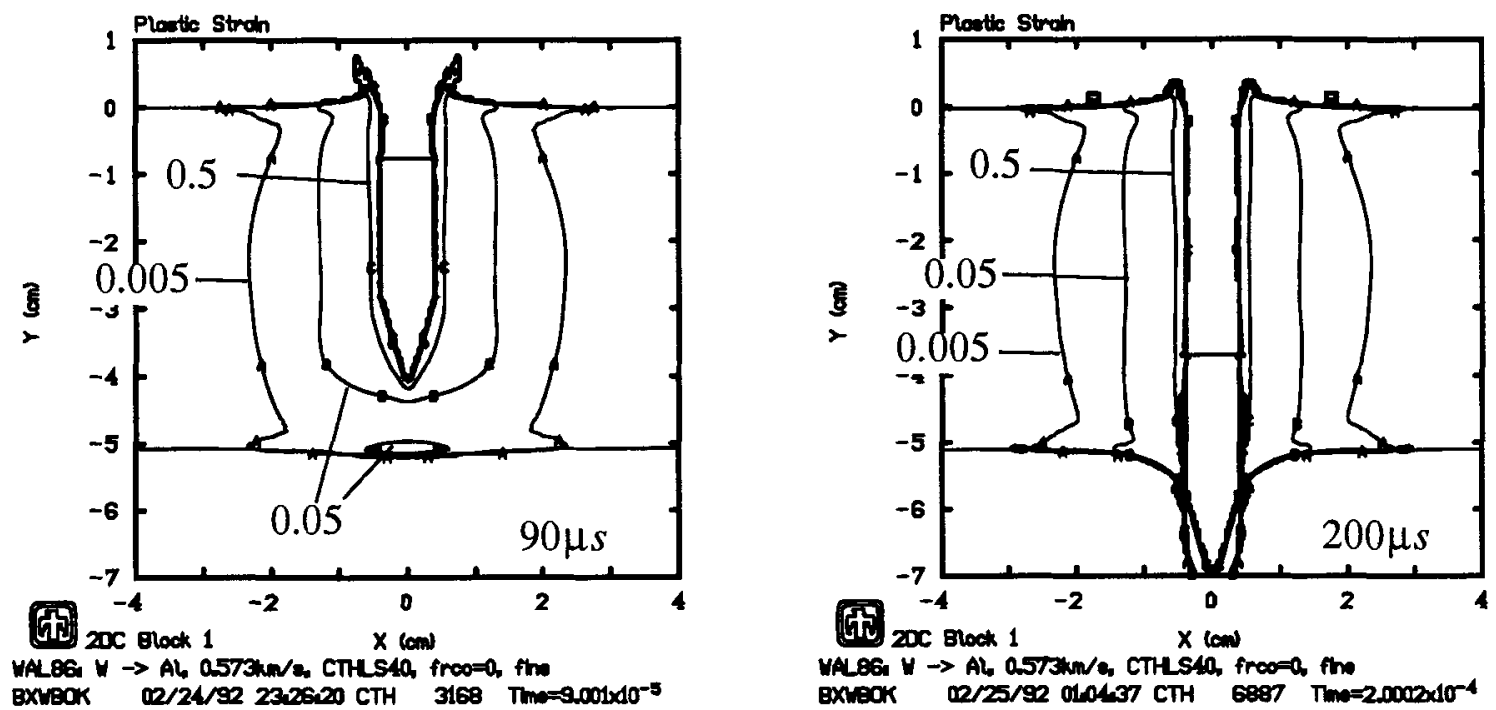

Figure 4.6. Contours of equivalent plastic strain. 


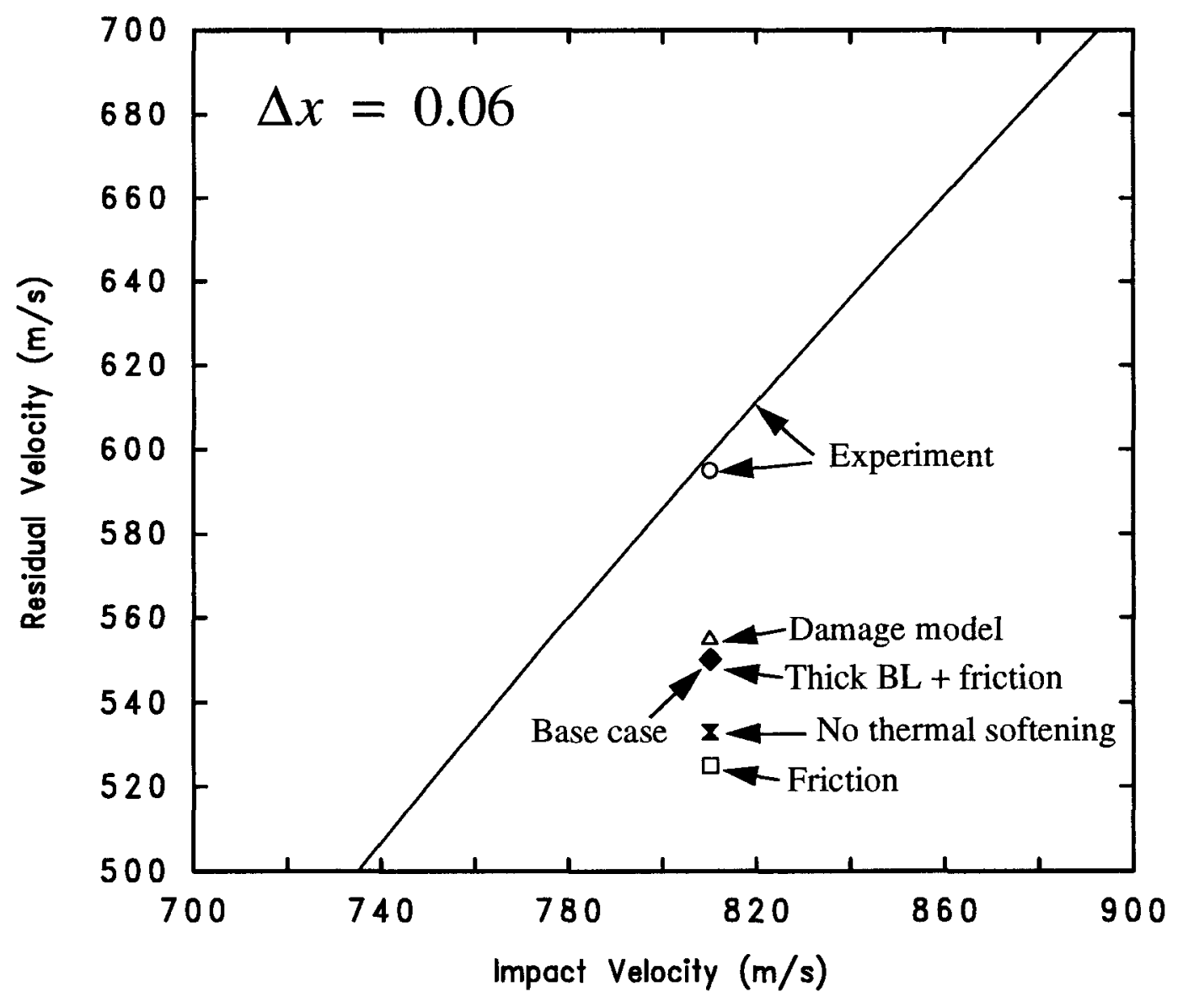

Figure 4.7. Residual velocities for variations with impact velocity $810 \mathrm{~m} / \mathrm{s}$. The points labeled "Base case" and "Thick BL + friction" overlap. 


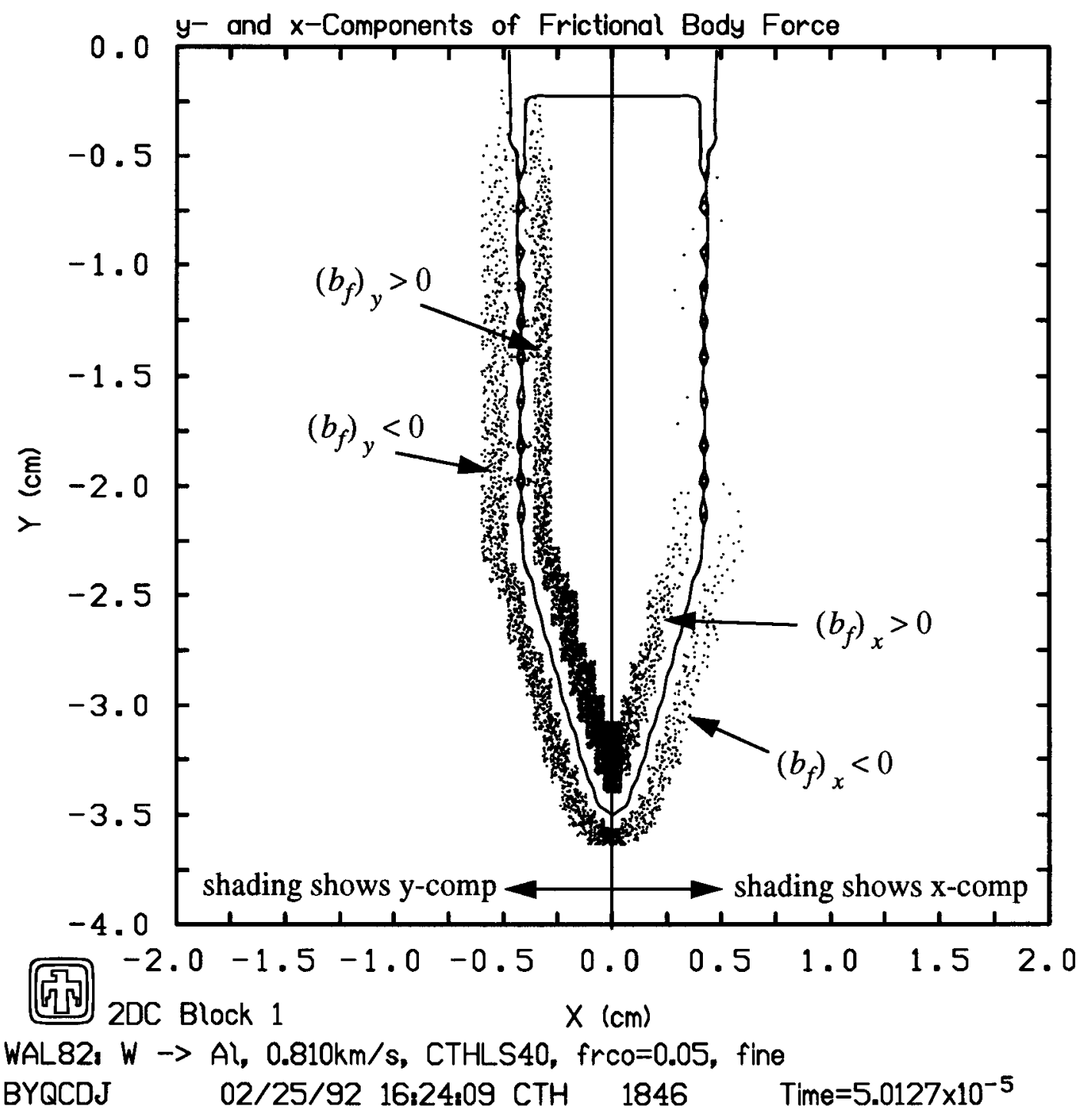

Figure 4.8. Distribution of frictional body force density. 

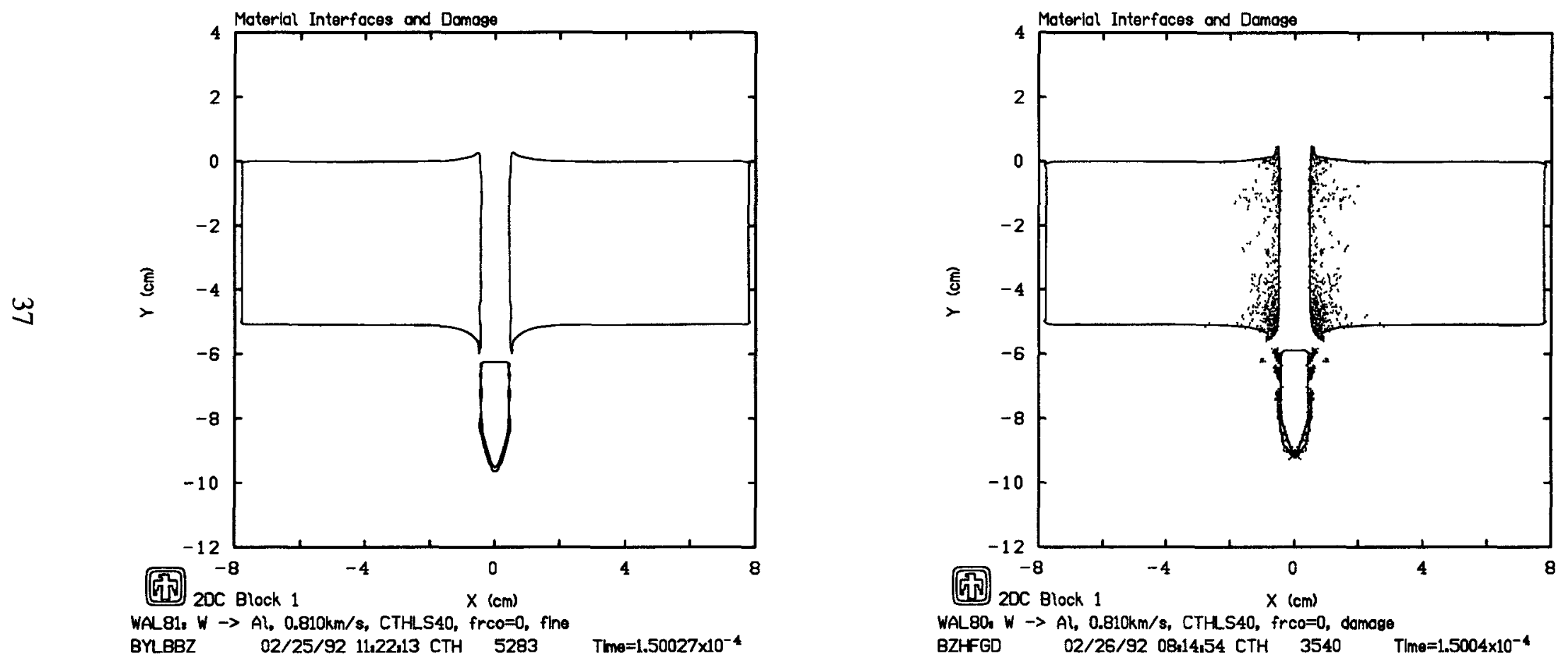

Figure 4.9. Results with (right) and without (left) the Johnson-Cook fracture model, impact velocity $810 \mathrm{~m} / \mathrm{s}$. Shading indicates damage. 
,

"
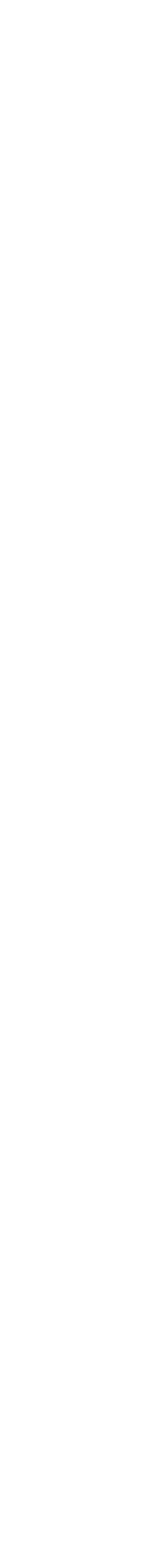
.

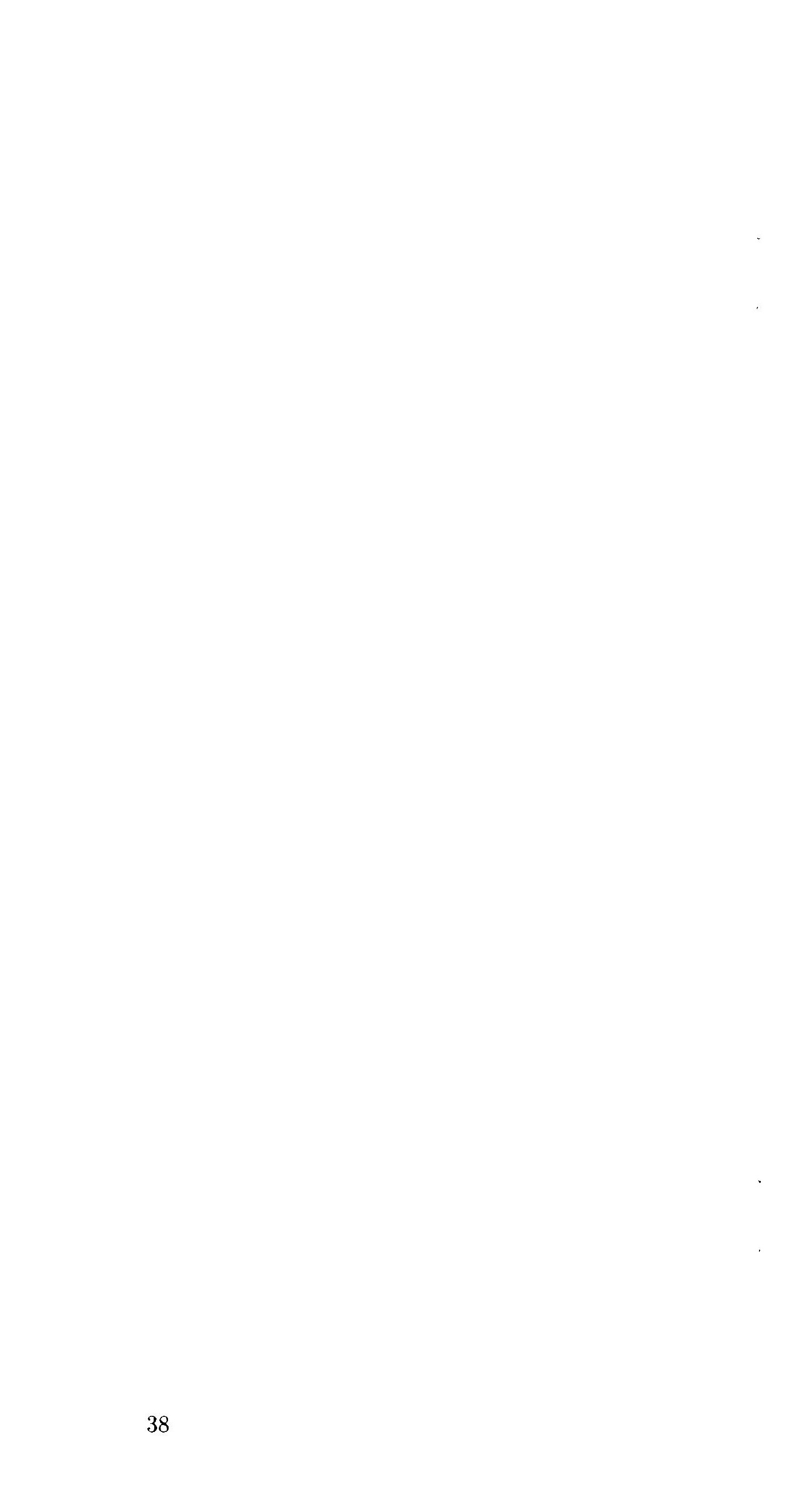




\section{Discussion}

The main source of error in the boundary layer algorithm described here is that it causes an effective enlargement of a penetrator. This occurs because it locates the slip layer a distance of one or two cell widths outside the penetrator surface. This causes the sliding to be predicted at a radius slightly larger than where it actually occurs, which is at the material interface. The effect is to introduce an error of order $\Delta x$ into the result. The only way at present to reduce this effective enlargement is to make the mesh finer. Future work may include attempts to compensate in some way for the forces on the penetrator due to this error.

The general approach taken in the boundary layer algorithm differs in a fundamental way from previous approaches in the Eulerian numerical modeling of sliding interfaces between solids. Previous methods that the author is aware of focus only on refinements of the treatment of mixed cells. This emphasis on mixed cells is an outgrowth of the general philosophy that has prevailed in the development of Eulerian codes, which is to provide greater and greater sophistication in all aspects of the treatment of mixed cells, including hydrodynamics, thermomechanics, equations of state, and interface tracking. The parts of a typical multi-material Eulerian wavecodes dealing with mixed cells are by far the most complicated parts of the code as a whole, and they tend to be the most difficult to justify on physical or mathematical grounds. The current state of the art in the treatment of fluids in mixed Eulerian cells does not inspire great hope for the development of accurate treatments of solids, which in many ways are much more complex than fluids.

In contrast, the boundary layer approach almost entirely avoids the issue of mixed cells. The general idea is to spread the physical interactions between sliding surfaces through a layer of finite thickness. This is similar to the effect of artificial viscosity in shock wave calculations, which spreads the shock over several cells while preserving the overall physical response.

Extension of the algorithm to three dimensions is straightforward in principle. The main issue to be resolved concerns the availability in central memory of all the data required for the averaging calculations performed for boundary layer cells, as in the evaluation of the average relative velocity $\overline{\mathbf{V}}$. In $\mathrm{CTH}$, only a limited number of planes of constant $z$-coordinate are readily accessible at any given time. It appears that the necessary volume required for averaging will, in general, exceed this number of planes. 


\section{ACKNOWLEDGMENT}

Helpful discussions with Michael J. Forrestal are gratefully acknowledged. 


\section{References}

[1] J. M. McGlaun, S. L. Thompson, and M. G. Elrick, CTH: A three-dimensional shock wave physics code, Int. J. Impact Engng. 10 (1990) 351-360.

[2] C. E. Anderson, Jr. and J. D. Walker, An examination of long-rod penetration, Int. J. Impact Engng. 11 (1991) 481-501

[3] M. J. Forrestal, V. K. Luk, and N. S. Brar, Perforation of aluminum armor plates with conical-nose projectiles, Mech. Mater. 10 (1990) 97-105.

[4] G. R. Johnson and W. H. Cook, A constitutive model and data for metals subjected to large strains, high strain rates and high temperatures, in Seventh International Symposium on Ballistics, The Hague, Netherlands (1983).

[5] T. W. Bjerke, J. A. Zukas, and K. D. Kimsey, Penetration performance of tungsten alloy penetrators with L/D ratios of 1 to $1 / 32$, BRL-TR-3246, Ballistic Research Laboratory, Aberdeen, MD (1991)

[6] L. N. Kmetyk and P. Yarrington, Cavity dimensions for high velocity penetration events - a comparison of calculational results with data, SAND88-2693, Sandia National Laboratories, Albuquerque, NM (1989)

[7] G. R. Johnson and W. H. Cook, Fracture characteristics of three metals subjected to various strains, strain rates, temperatures, and pressures, Engin. Frac. Mech. 21 (1985) 31-48.

[8] G. R. Johnson and T. J. Holmquist, Test data and computational strength and fracture model constants for 23 materials subjected to large strains, high strain rates, and high temperatures, LA-11463-MS, Los Alamos National Laboratory, Los Alamos, NM (1989). 


\section{Distribution}

Charles E. Anderson (3)

Southwest Research Institute

PO Drawer 28510

San Antonio, TX 78284

Attn.: C. E. Anderson, C. J. Kuhlman, J. D.

Walker

John May (4)

Kaman Sciences Corporation

1500 Garden of the Gods Rd.

Colorado Springs, CO 80933

Attn.: S. Diehl, S. Jones, J. May, V. Smith

Dennis L. Orphal (3)

California Research and Technology, Inc.

5117 Johnson Dr.

Pleasanton, CA 94588

Attn.: D. L. Orphal, P. N. Schneidewind, S. P.

Segan

\section{Mark Majerus}

California Research and Technology, Inc.

PO Box 2229

Princeton, NJ 08543-2229

Director (10)

US Army Ballistic Research Laboratory

Attn.: SLCBR-TB-P (Kent D. Kimsey)

Aberdeen Proving Ground, MD 21005-5066

Attn: R. Coates, Y. Huang, K. Kimsey, H.Meyer, G. Randers-Pehrson, D. Scheffler, S. Segletes, G. Silsby, B. Sorenson, J. A. Zukas

Eric Fahrenthold

Department of Mechanical Engineering

The University of Texas at Austin

Austin, TX 78712
Hans Mair (5)

Naval Surface Warfare Center

10901 New Hampshire Ave.

Silver Spring, MD 20903-5000

Attn.: W. Holt, K. Kim, H. Mair, W. Reed, P.

Walters

Lt. Col. Joseph Beno (2)

Defense Advanced Research Projects Agency 1500 Wilson Blvd.

Arlington, VA 22209-2308

Attn: J. Beno, J. Richardson

Wright Laboratory (2)

Computational Mechanics Section

Eglin AFB, FL 32542-5434

Attn: J. Collins, J. Foster

Wright Laboratory (6)

Technology Assessment Branch

Eglin AFB, FL 32542-5434

Attn: D. Brubaker, R. Hunt, S. Joyce, B.

Patterson, M. Schmidt, D. Zappola

Firooz Allahdadi (3)

Phillips Laboratory.

Nuclear Technology Branch

Kirtland AFB, NM 87117-6008

Attn: F. Allahdadi, D. Fulk, J. Secary

Carlos Marino

Industry, Science, and Technology Department

Cray Research Park

655 E. Lone Oak Dr.

Eagan, MN 55121

Brent Webb

Battelle Pacific Northwest Laboratories

Mail Stop K6-47

PO Box 999

Richland, WA 99352 
John Tipton

US Army Engineer Division

HNDED-SY

PO Box 1600

Huntsville, AL 35807

Gene Carden

University of Alabama

PO Box 870278

Tuscaloosa, AL 35487-0278

Doug Everhart

Battelle Memorial Institute

505 King Ave.

Columbus, OH 43201-2693

Dan Bowlus (3)

Naval Underwater Systems Center

Mail Code 8123

Newport, RI 02841-5047

Attn: D. Bowlus, G. Letiecq, S. Prashaw

Bill Tanner

Space Science Laboratory

Baylor University

PO Box 7303

Waco, TX 76798

Steve Zilliacus

David Taylor Research Center

Mail Code 1750.1

Bethesda, MD 20084

Eric Christiansen

NASA Johnson Space Center

Space Science Branch/SN3

Houston, TX 77058

G. R. Johnson (2)

Alliant Techsystems Inc.

7225 Northland Dr.

Brooklyn Park, MN 55428

Attn: G. Johnson, O. Souka
Stan Fink

TRW Defense Sytems Group

Bldg. 134-9048

One Space Park

Redondo Beach, CA 90278

Kim Parnell

Failure Analysis Associates, Inc.

149 Commonwealth Ave.

PO Box 3015

Menlo Park, CA 94025

David Tenenbaum

U. S. Army Tank Automotive Command

RD\&E Center

Survivability Division

Mail Code MASTA-RSS

Warren, MI 48397-5000

Trent R. Logan

Rockwell International Group

Mail Code NA40

12214 Lakewood Blvd.

Downey, CA 90242

Scott Hill

NASA Marshall Space Flight Center

Mail Code ED52

Redstone Arsenal

Huntsville, AL 35812

Steve Herrick

Textron Defense Systems

Mail Stop 1115

201 Lowell St.

Wilmington, MA 01887

Julius W. Enig

Enig Associates, Inc.

11120 New Hampshire Ave.

Suite 500

Silver Spring, MD 20904-2633 
Frank Maestas

Principal Engineer

Applied Research Associates

4300 San Mateo Blvd.

Suite A220

Albuquerque, NM 87110

Larry Brown

Instrumentation Development

Denver Research Institute

University Park

Denver, CO 80208

Mark Smith

Aerophysics Branch

Calspan Corporation/AEDC Operations

MS 440

Arnold AFB, TN 37389

John W. Wolfsberger (2)

Teledyne Brown Engineering

Cummings Research Park

300 Sparkman Dr., NW

PO Box 070007

Huntsville, AL 35807-7007

Attn: J. Wolfsberger, B. Singh

William Nester

Oak Ridge National Laboratory

PO Box 2009

Oak Ridge, TN 37831-8058

William J. Tedeschi

DNA/SPSP

6801 Telegraph $\mathrm{Rd}$.

Alexandria, VA 22310

R. Rohani

US Army Engineer Waterways Experiment

Station

Attn: CEWES-SD

3909 Halls Ferry Rd.

Vicksburg, MS 39180-6199

\section{J. Glimm}

Dept. of Applied Mathematics

State University of New York At Stony Brook

Stony Brook, NY 11794-3600

David J. Benson

Dept. of AMES R-011

University of California San Diego

La Jolla, CA 92093

Lockheed Company (2)

Organization 81-12

Building 157

Sunnyvale, CA 94088-3504

Attn: Yong-il Choo, Eric Matheson

D. Matuska

Orlando Technology, Inc.

PO Box 855

Shalimar, FL 32579

L. Seaman

SRI International

333 Ravenswook Ave.

Menlo Park, CA 94025

M. Alme

R\&D Associates

2100 Washington Blvd.

Arlington, VA 22204-5706

CIA

6219 Lavell Ct.

Springfield VA 22152

Attn: G. Lyles, J. Walton

Los Alamos National Laboratory

Mail Station 5000

PO Box 1663

Los Alamos, NM 87545

Attn: T. F. Adams, MS F663

Attn: B. I. Bennett, MS B221

Attn: S. T. Bennion, MS F663

Attn: W. Birchler, MS G787

Attn: P. J. Blewett, MS F663 
Attn: M. W. Burkett, MS G787

Attn: E. J. Chapyak, MS F663

Attn: R. A. Clark, MS B257

Attn: G. E. Cort, MS G787

Attn: B. J. Daly, MS B216

Attn: J. K. Dienes, MS B216

Attn: H. Flaush, MS C936

Attn: R. P. Godwin, MS F663

Attn: F. Harlow, MS B216

Attn: W. B. Harvey, MS F663

Attn: B. L. Holian, MS J569

Attn: K. S. Holian, MS B221

Attn: J. W. Hopson, MS B216

Attn: H. Horak, MS C936

Attn: M. L. Hudson, MS J970

Attn: N. L. Johnson, MS B216

Attn: J. F. Kerrisk, MS G787

Attn: M. Klein, MS F669

Attn: W. H. Lee, MS B226

Attn: D. Mandell, MS F663

Attn: L. G. Margolin, MS D406

Attn: G. H. McCall, MS B218

Attn: J. K. Meier, MS G787

Attn: R. W. Meier, MS G787

Attn: A. T. Oyer, MS G787

Attn: M. Rich, MS F669

Attn: M. Sahota, MS B257

Attn: W. Sparks, MS F663

Attn: D. Tonks, MS B267

Attn: H. E. Trease, MS B257

Attn: L. Witt, MS C936

Attn: Robert Young, MS K574

University of California

Lawrence Livermore National Laboratory

7000 East Ave.

PO Box 808

Livermore, CA 94550

Attn: D. E. Burton, MS L-18

Attn: R. B. Christensen, MS L-35

Attn: J. M. LeBlanc, MS L-35

Attn: W. Moran

Attn: M. J. Murphy, MS L-368

Attn: J. E. Reaugh, MS L-290

Attn: D. J. Steinberg, MS L-35
Attn: R. E. Tipton, MS L-35

Attn: C. E. Rhoades, MS L-298

\section{Sandia Internal}

$\begin{array}{ll}1400 & \text { E. H. Barsis } \\ 1420 & \text { W. J. Camp } \\ 1421 & \text { S. S. Dosanjh } \\ 1421 & \text { D. R. Gardner } \\ 1425 & \text { J. H. Biffle } \\ 1425 & \text { S. W. Attaway } \\ 1425 & \text { S. T. Montgomery } \\ 1430 & \text { J. R. Asay } \\ 1431 & \text { J. M. McGlaun } \\ 1431 & \text { K. Budge } \\ 1431 & \text { M. G. Elrick } \\ 1431 & \text { E. S. Hertel } \\ 1431 & \text { R. J. Lawrence } \\ 1431 & \text { J. S. Peery } \\ 1431 & \text { S. Petney } \\ 1431 & \text { A. C. Robinson } \\ 1431 & \text { T. G. Trucano } \\ 1431 & \text { M. Wong } \\ 1431 & \text { CTH Day File } \\ 1431 & \text { L. Yarrington } \\ 1432 & \text { P. Yarrington } \\ 1432 & \text { R. L. Bell } \\ 1432 & \text { W. T. Brown } \\ 1432 & \text { P. J. Chen } \\ 1432 & \text { J. E. Dunn } \\ 1432 & \text { H. E. Fang } \\ 1432 & \text { A. V. Farnsworth } \\ 1432 & \text { G. I. Kerley } \\ 1432 & \text { M. E. Kipp } \\ 1433 & \text { F. R. Norwood } \\ 1433 & \text { J. L. W. R. Martinez } \\ 1432 & \text { S. A. Silling (15) } \\ 1432 & \text { P. A. Taylor } \\ 1433 & \text { P. L. Stanton } \\ 1433 & \text { J. A. Ang } \\ 1433 & \text { M. Boslough } \\ 1433 & \text { L. C. Chhabildas } \\ 1433 & \text { M. D. Furnish } \\ 1433 & \text { D. E. Grady } \\ 1433 & \text { J. Swegle } \\ 143 & \end{array}$




\begin{tabular}{|c|c|c|c|}
\hline 1434 & J. J. Allen & 6463 & M. Berman \\
\hline 1434 & L. Branstetter & 6463 & K. Boyack \\
\hline 1434 & J. Dohner & 8240 & C. W. Robinson \\
\hline 1434 & C. R. Dohrmann & 8241 & G. A. Benedetti \\
\hline 1434 & G. R. Eisler & 8241 & M. L. Chiesa \\
\hline 1434 & J. T. Foley & 8241 & L. E. Voelker \\
\hline 1434 & D. W. J.obitz & 8242 & M. R. Birnbaum \\
\hline 1434 & D. B. Longcope & 8242 & J. L. Cherry \\
\hline 1434 & E. L. Marek & 8242 & J. J. Dike \\
\hline 1434 & J. Pott & 8242 & B. L. Kistler \\
\hline 1434 & J. R. Red-Horse & 8242 & A. McDonald \\
\hline 1434 & D. J. Segalman & 8242 & V. D. Revelli \\
\hline 1510 & J. C. Cummings & 8242 & L. A. Rogers \\
\hline 1511 & J. S. Rottler & 8242 & K. V. Trinh \\
\hline 1512 & A. C. Ratzel & 8242 & L. I. Weingarten \\
\hline 1514 & H. S. Morgan & 8243 & M. L. Callabresi \\
\hline 1514 & V. L. Bergmann & 8243 & D. J. Bammann \\
\hline 1514 & B. J. Thorne & 8243 & V. K. Gabrielson \\
\hline 1544 & C. R. Adams & 8244 & S. K. Griffiths \\
\hline 1544 & K. W. Gwinn & 8244 & C. M. Hartwig \\
\hline 1544 & E. Kephart & 8245 & R. J. Kee \\
\hline 1544 & F. J. Mello & 8245 & W. E. Mason \\
\hline 1544 & K. E. Metzinger & $8523-$ & 2 Central Technical Files \\
\hline 1544 & E. D. Reedy & 9014 & J. W. Keizur \\
\hline 1544 & K. W. Schuler & 9122 & R. W. Ostensen \\
\hline 1544 & G. D. Sjaardema & 9122 & R. O. Nellums \\
\hline 1544 & A. M. Slavin & 9123 & J. M. Holovka \\
\hline 1544 & P.P. Stirbis & 9123 & M. J. Forrestal \\
\hline 1544 & R. K. Thomas & 9123 & J. T. Hitchcock \\
\hline 1550 & C. W. Peterson & 9123 & V. K. Luk \\
\hline 1551 & J. K. Cole & 9123 & M. J. Sagartz \\
\hline 1552 & D. D. McBride & 9123 & C. W. Young \\
\hline 1553 & W. L. Hermina & 9128 & M. M. Hightower \\
\hline 1554 & D. P. Aeschliman & 9311 & A. J. Chabai \\
\hline 1555 & W. P. Wolfe & 9311 & T. Bergstresser \\
\hline 1556 & W. L. Oberkampf & & \\
\hline 1600 & W. Herrmann & & \\
\hline 2513 & D. E. Mitchell & & \\
\hline 3141 & S. A. Landenberger (5) & & \\
\hline 3145 & $\begin{array}{l}\text { Document Processing, for DOE/OSTI } \\
\text { (8) }\end{array}$ & & \\
\hline 3151 & G. C. Claycomb (3) & & \\
\hline 5111 & W. J. Patterson & & \\
\hline 6418 & S. L. Thompson & & \\
\hline 6418 & L. N. Kmetyk & & \\
\hline 6429 & K. E. Washington & & \\
\hline
\end{tabular}

